\title{
Ayurveda Rasayana as antivirals and immunomodulators: potential applications in COVID-19
}

\author{
Rajeshwari Singh $^{1} \cdot$ Sumeet Goel ${ }^{1} \cdot$ Pascale Bourgeade $^{2} \cdot$ Lotfi Aleya $^{2} \cdot$ Devesh Tewari $^{3}$ (I)
}

Received: 2 February 2021 / Accepted: 27 August 2021 / Published online: 7 September 2021

(C) The Author(s), under exclusive licence to Springer-Verlag GmbH Germany, part of Springer Nature 2021

\begin{abstract}
Coronavirus disease (COVID-19) has been declared as a pandemic by the World Health Organization with rapid spread across 216 countries. COVID-19 pandemic has left its imprints on various health systems globally and caused immense social and economic disruptions. The scientific community across the globe is in a quest for digging the effective treatment for COVID-19 and exploring potential leads from traditional systems of healthcare across the world too. Ayurveda (Indian traditional system of medicine) has a comprehensive aspect of immunity through Rasayana which is a rejuvenation therapy. Here we attempt to generate the potential leads based on the classical text from Ayurveda in general and Rasayana in particular to develop effective antiviral and/or immunomodulator for potential or adjunct therapy in SARS-CoV-2. The Rasayana acts not only by resisting body to restrain or withstand the strength, severity or progression of a disease but also by promoting power of the body to prevent the manifestation of a disease. These Rasayana herbs are common in practice as immunomodulator, antiviral and protectives. The studies on Rasayana can provide an insight into the future course of research for the plausible development of effective management of COVID-19 by the utilization and development of various traditional systems of healthcare. Keeping in view the current pandemic situation, there is an urgent need of developing potential medicines. This study proposes certain prominent medicinal plants which may be further studied for drug development process and also in clinical setup under repurposing of these herbs.
\end{abstract}

Keywords AYUSH $\cdot$ Antiviral $\cdot$ Immunity $\cdot$ Traditional medicine $\cdot$ Repurposing

\section{Introduction}

Viruses and associated ailments have always been considered as the greatest challenge for humanity and the epicentre of science, agronomy and healthcare system. Numerous viral infections, for instance, measles, poliomyelitis, rabies and yellow fever, are controlled and very rare these days. This is due to vaccination and other measures of public health. However,

\section{Responsible Editor: Philippe Garrigues}

Lotfi Aleya

lotfi.Aleya@univ-fcomte.fr

$\checkmark$ Devesh Tewari

dtewari3@gmail.com

1 Central Council for Research in Ayurvedic Sciences, Ministry of AYUSH, Government of India, Janakpuri, New Delhi 110058, India

2 Chrono-Environnement Laboratory, UMR CNRS 6249, Bourgogne Franche-Comté University, F-25030 Besançon Cedex, France

3 Department of Pharmacognosy, School of Pharmaceutical Sciences, Lovely Professional University, Phagwara, Punjab, India many new viruses emerge periodically which has a disastrous effect on an individual and society (Enquist 2009). Among many such viruses, coronaviruses (CoVs) are a group of RNA viruses causing diseases in mammals, including humans. CoVs cause mild to moderate upper respiratory infections in humans, which lasts for few days and may be lethal in many cases ( $\mathrm{Li}$ et al. 2020). The outbreak of new disease in Wuhan, China, in December 2019 was later named as coronavirus disease 2019 (COVID-19), and the causative virus was identified as novel coronavirus (n-CoV-2) (Luan et al. 2020; Singhal 2020). The main clinical symptoms of COVID-19 patients are fever, cough, body ache and myalgia. It is also observed that diarrhoea and nausea may present initially prior to fever, and sometimes respiratory failure also occurs due to severe alveolar damage in patients (Chen et al. 2020). The rapid progression of disease sometimes leads to various organ dysfunctions and even death in severe cases (Wang et al. 2020).

This COVID-19 pandemic has left its imprints on various health systems globally and caused social and economic disruptions. Various efforts are underway for exploring the best 
possible treatment for COVID-19. The outbreak of COVID19 infiltration in India was reported from a student who returned from Wuhan on January 30, 2020. Later on, two more cases were reported in February 2020 (Ghosh et al. 2020; Kaushik et al. 2020c). Afterwards, the number increases in March, and there was a surge in the latter half of April 2020. The Government of India took various measures like travel restrictions, community surveillance, institutional quarantine, identification of hotspots or containment zones and several others along with strict lockdown that had to flatten the India's case growth trajectory curve during the first surge of COVID-19 (Pal and Yadav 2020). However, there is a surge of cases again in April 2021 which is presumed to be the second wave of the pandemic and became much more disastrous in comparison to the first one. So far, India has reported more than 20.2 million cases on May 4, 2021. The twopronged strategy to control the surge of second wave is massive vaccination and lessen the transmission of severe acute respiratory syndrome (SARS)-CoV-2 (Lancet 2021). Though biomedicine has enormously helped in managing symptomatic treatment and critical care of SARS-CoV-2, the systemic approach of Ayurveda, Yoga, Naturopathy, Unani, Siddha, Sowa-Rigpa and Homoeopathy (AYUSH) systems towards strengthening the host defence mechanism for plausible prophylaxis and prevention may play a pivotal role (Kotecha 2021).

Traditional medicines are important source for developing effective treatment against various ailments. These can be used in the prophylactic measure in light that over $75 \%$ of the population in developing countries rely on herbs and use traditional remedies for primary healthcare (Diallo et al. 1999; Tewari et al. 2020). In addition, a large number of new molecules are directly obtained either from natural products or from their derivatives (Tewari et al. 2019; Newman and Cragg 2020). Ayurveda is the Indian traditional healthcare system which has been used for centuries to deal with various ailments (Mukherjee et al. 2017). It is considered as a complete self-sustainable system of medicine (Katoch et al. 2017). Various Ayurveda formulations are in practice to limit the fevers of any origin (Kaushik et al. 2020a, b) as immune herbs for prevention and curation. Several of these herbs have been extensively studied for their immune-enhancing, modulating and antiviral effects (Dhawan 2012; Jadhav et al. 2012), for instance, Phyllanthus emblica L. (Amalaki), Withania somnifera (L.) Dunal (Ashwagandha), Tinospora cordifolia (Thunb.) Miers. (Guduchi) and Glycyrrhiza glabra L. (Yashtimadhu). The traditionally used herbs are considered safer and cost-effective than their synthetic counterparts. Many times, they also served as a primary source of various pharmaceutical agents which help in limiting the infectious and non-infectious diseases (Kaushik et al. 2018; Sharma et al. 2021). Extensive studies may provide an insight into the future course of research for the plausible development of effective COVID-19 management. This can be achieved by the utilization and development of various natural product-based medicines.

Various Materia Medica of Ayurveda conceptualize a group of herbs, formulations and therapies for enhancing body resistance under the comprehend term Rasayana. The specific properties possessed by these herbs of Rasayana category are evaluated and validated in various scientific studies (Chulet and Pradhan 2009). These botanicals are reported to be rich in numerous specialized metabolites responsible for immune modulation, antioxidant activities, neurodegenerative disorders and rejuvenators and may act as nutritional supplements (Thakur et al. 2007; Doshi et al. 2013). Here we provide a comprehensive detail on some possible potential leads from Ayurveda to develop effective antiviral and/or immunomodulator for prophylactic or adjunct therapy in SARS-CoV-2.

\section{Methodology}

The literature search was conducted on two broad dimensions. Initially, the classical text was searched to shortlist the plants followed by advanced search to explore the available scientific evidences in various search engines. In the classical literature search, an extensive review was done in Charaka Samhita to identify the Rasayana drugs. Charaka Samhita is one of the oldest, most authentic and the most widely practised treatises on Ayurveda. The text in Charaka Samhita is written in the form of verses or shloka and partly in prose. The compendium comprises 120 chapters categorized into eight sections or Sthana. Each section pertained to a specific subject. Chapters 31-60 are named as Chikitsa Sthana which consists of 30 chapters that deal with the study of preservation of health and prevention and management of various diseases. The first chapter in this is on Rasayana which is further divided into four sub-sections (or sub-chapters). These four subsections consist of 129 medicines (Rasayana) in the form of various single and compound herbal and herbo-mineral formulations. Out of these, 63 single or plant-based formulations have herbs and certain metals as a main ingredient. Upon excluding metals, alkali, dietary items and herbs whose identity was not confirmed, the remaining 50 was single herbs. These 50 herbs were scanned for antiviral and immunomodulator activities. A detailed methodology is presented in Fig. 1.

After selection of these 50 herbs, an extensive literature search was performed through various web databases like Pubmed, ScienceDirect, Scopus and Google Scholar by Boolean information retrieval method (Pohl et al. 2010; Tewari et al. 2017, 2018). The botanical name of the plants with "AND" operator followed by keywords "antiviral," "coronavirus," "covid-19," "immunomodulatory" and "immunity" was searched. The period of article analysis was from the 
Fig. 1 Schematic representation of the methodology for shortlisting the Rasayana drugs

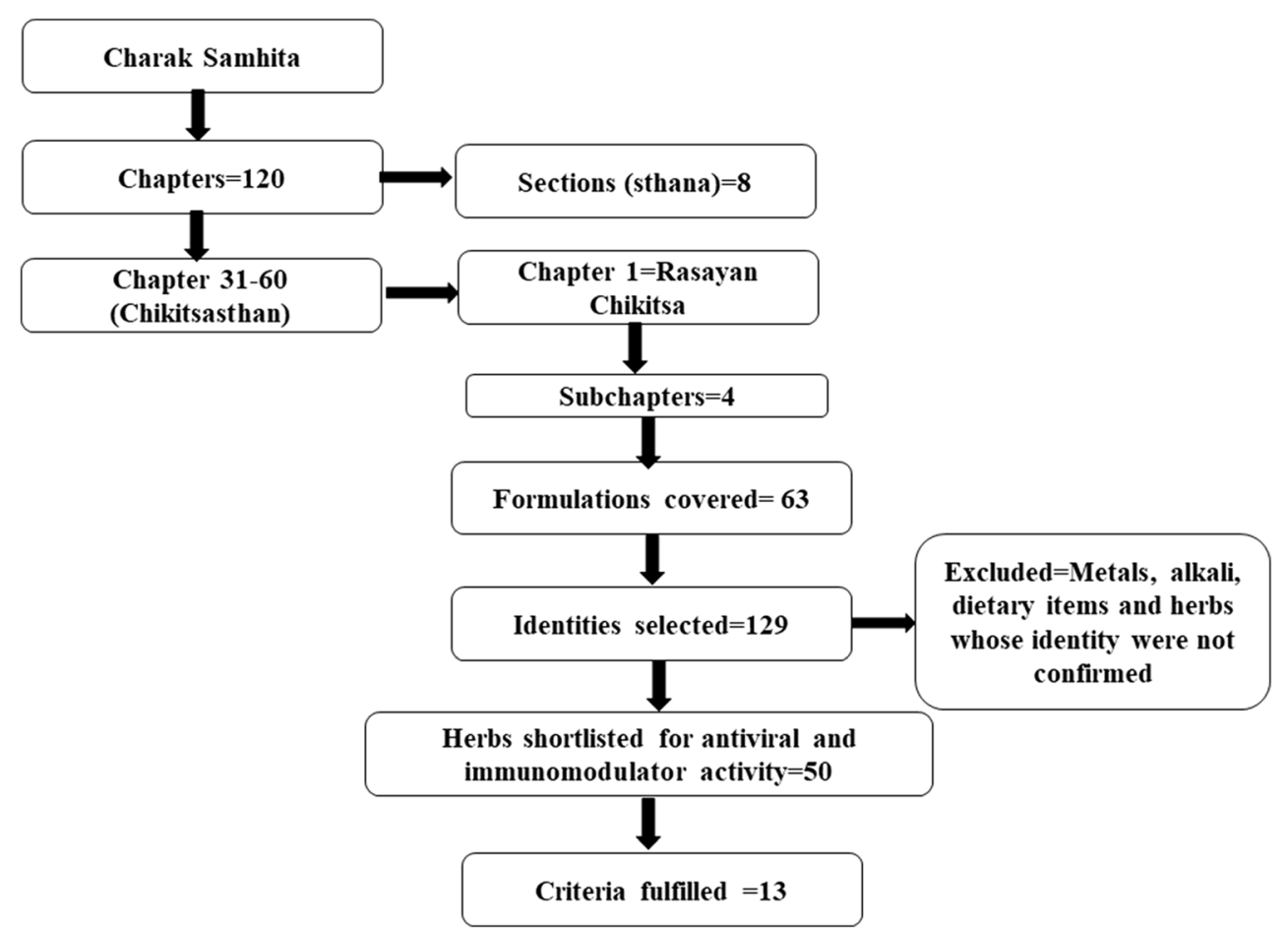

last 20 years published in English language. Finally, 13 herbs were shortlisted fulfilling the criteria of having potential antiviral and immune modulation activities. A process of thorough discussions among authors and subject experts depending on their usage, i.e. most commonly used, known safety profiles, better availability and Jwar hara (virtue of their utility against fever) properties as per Ayurveda, was adopted to shortlist the potential herbs from the screened ones. In addition, we have also explored the clinical trials registered for these shortlisted herbs along with various in vitro, in silico and in vivo studies to understand the potential targets against SARS-CoV-2 or SARS-CoV and MERS.

\section{SARS-CoV-2, immune system and Ayurvedic perspective}

Recent studies (Urra et al. 2020; de Candia et al. 2021) have reported that SARS-CoV-2 considerably affects the immune system through T cells, particularly CD4+ and CD8+ which have a substantial antiviral role in fighting the pathogens. However, it is associated with risk of elevated immune response causing autoimmunity or inflammation (Cecere et al. 2012). CD4+ T cells help in production of viral-specific antibodies through T cell-dependent B cells, while CD8+ T cells are cytotoxic and kill virus-infected cells. Further, CD8+ T cells are major players in clearing of the viral load and also in causing inflammatory damage in the pulmonary interstitium in SARS-CoV-infected patient (Maloir et al. 2018).
T helper (Th) cells act by producing pro-inflammatory cytokines via nuclear factor kappa-light-chain-enhancer of activated B cells (NF-kB) signaling (Manni et al. 2014), and response of $\mathrm{T}$ cell is emphasized in order to protect against viral infections such as COVID-19 (Luo et al. 2020).

The cytokines interleukin (IL)-17 recruit monocytes and neutrophils at the infection site and activate other downstream cascades of cytokines, viz. IL-1, IL-6, IL-8, IL-21, tumor necrosis factor (TNF)- $\beta$ and monocyte chemoattractant protein1 (MCP-1) (Bunte and Beikler 2019). However, earlier studies have also reported a crucial role of both $\mathrm{CD} 8+$ and $\mathrm{CD} 4+\mathrm{T}$ cells in SARS-CoV clearance (Chen et al. 2020). It is also observed that development of SARS-CoV-specific neutralizing antibodies requires CD4+ T helper cells (Janice Oh et al. 2012). In certain cases, there is an overwhelmed immune response causing a serious inflammatory reaction causing apoptosis of host cell (Xu et al. 2020) by cascade of cytokine release leading to a life-threatening condition by cytokine release syndrome (CRS). It is more serious among patients with other comorbidities like cardiac ailments, diabetes mellitus, arterial hypertension and hepatic or renal diseases (Guan et al. 2020). It becomes imperative to explore the specific approach where a tailor-made immune response is warranted, with an exact mechanism and reason of how in certain cases the exaggerated and abnormal immune response causing cytokine storm is present.

Ayurveda advocates multimodal approach to the disease, viz. nidanaparivarjana (avoidance of the etiological factors), apakarshana (removing the root cause) and prakritivighata (disease modifying or preparation of internal environment of 
the body hostile for the infectious agent). Ayurveda system believes in the concept of prevention through lifestyle and dietary management along with Rasayana therapy, which is considered as an effective measure in the prevention of disease by providing non-specific immunity (Kumar et al. 2012). Rasayana which is specific to the respiratory tract has been studied and found to be effective in the management of viral respiratory tract infections like dengue. These herbs act by exerting non-specific immunity and acting as inhibitory sources against the crucial dengue receptor NS2B-NS3 (Bency 2018) or by eliminating the vectors (Thanigaivel et al. 2017) as in Chikungunya (Sharma et al. 2019).

A study was conducted on the clinical analysis cohort of COVID-19 patients based on principles of Ayurvedic nosology. It suggests that COVID-19 can be categorized as agantuka (caused due to external factor, i.e. infection) type of vata-kapha-pradhana-sannipata-jvara (fever involving all three dosha with dominance of vata-kapha) with pittanubandhatva (in association with pitta dosha) (Girija and Sivan 2020). It has been postulated that COVID-19 can be understood from the Ayurvedic perspective as vata-kapha (two of the three Dosha mentioned in Ayurveda) dominant sannipatajvara (fever involving all three dosha) of agantu origin with pittanubandha (Puthiyedath et al. 2020). In accordance with Ayurveda pathogenesis, initial prophylactic measures can be adopted by suggesting certain Rasayana therapy like hot infusion of Zingiber officinalis Roscoe (Shunthi), Tinospora cordifolia, Amritottar Kasaya (comprise of T. cordifolia, Z. officinalis and Terminalia chebula) and Samshamani Vati (preparation of T. cordifolia) in high-risk population. As the person contact with disease with its progression, it can be understood in different stages for management point of view (Kumar et al. 2021).

Many Rasayana herbs possess good immunomodulatory effect which can provide promising leads in boosting the immune system capacity. For instance, Phyllanthus emblica efficiently reduced pro-inflammatory cytokine (TNF and IL-1) levels and significantly upregulate anti-inflammatory cytokine (IL-10) concentration in an in vivo study (Chatterjee et al. 2011). In another study, T. cordifolia was found to possess immunomodulatory activity by improving the phagocyte function without affecting cell-mediated and humoral immune systems (Sachan et al. 2019). Various other herbs, viz. Vitex trifolia (Nirgundi bhed) and Sphaeranthus indicus L. (Gorakhmundi), have also been reported to reduce inflammatory cytokines through NF-kB pathway, which is responsible for respiratory distress in SARS-CoV (Alam et al. 2002). Andrographis paniculata (Burm. f.) Wall. Ex Nees (Kalmegh) is an important herb used in Ayurveda to treat variety of viral infections especially respiratory infections and dengue fever (Coon and Ernst 2004; Arora et al. 2011; Yarnell 2017; Kaushik et al. 2021). Studies reported that A. paniculata suppresses increased NOD-like receptor protein
3 (NLRP3), caspase- 1 and IL-1 $\beta$ molecules which are involved in the pathogenesis of SARS-CoV and likely SARSCoV-2 as well (Liu et al. 2020a, b).

It can be hypothesized that immunomodulators and immune adjuvant can play an important role in proper functioning of CD4+ and CD8+ cells as also reported for various Rasayana herbs too. Few herbs mentioned under the Ayurveda Rasayana like T. cordifolia and Glycyrrhiza glabra are reported for immune-enhancing effect through modulating the response of CD4+ and CD 8+ T cells against viral infections (Somarathna et al. 2010). Similarly, P. emblica is reported to enhance the immunity both in vitro and in vivo, especially in natural killer (NK) cell-induced cytotoxic activity (Huabprasert et al. 2012) which are detailed in the subsequent section of this paper. These Rasayana herbs can be used to ameliorate various symptoms of COVID-19. Though many medicinal plants have been identified, extensive research is required for the development of drug specific to SARSCoV-2. Therefore, it is important to explore the effect of these prescribed traditional medicines in SARS-CoV-2.

\section{Pathogenesis of COVID-19 and possible Ayurvedic interventions}

Coronavirus belongs to the family Coronaviridae which is further divided into four genera: alpha, beta, gamma and delta coronavirus. SARS-CoV-2 is closely related to beta-CoVs in phylogenetic studies (Pal et al. 2020). The genome of SARSCoV-2 is positive-sense single stranded RNA [(+) ssRNA] with a $5^{\prime}$-cap, $3^{\prime}$ UTR poly(A) tail with embedded 14 open reading frames (ORFs), encoding non-structural proteins (NSPs) for virus replication and assembly processes; structural proteins including spike (S), envelope (E), membrane/ matrix (M) and nucleocapsid $(\mathrm{N})$; and accessory protein (Mohamadian et al. 2021). NSP3, NSP9, NSP10, NSP12, NSP15 and NSP16 are the major NSPs among other polyprotein ppla (nsp1-11) and pplab (nsp1-16) which play major role in viral replication (Rohaim et al. 2021).

$\mathrm{S}$ protein is a transmembrane protein that facilitates the binding of viral envelop to angiotensin-converting enzyme 2 (ACE2) receptors expressed on host cell surfaces (Noman et al. 2021). N protein attaches to the viral genome and is involved in RNA replication, virion formation and immune evasion. The nucleocapsid protein also interacts with the nsp3 and $\mathrm{M}$ proteins. $\mathrm{M}$ protein promotes the assembly and budding of viral particles, and $\mathrm{E}$ protein facilitates the production, maturation and release of virions (Schoeman and Fielding 2019). The most complex component of the CoV genome is the receptor-binding domain (RBD) in the S protein. Six RBD amino acids are necessary for attaching to the ACE2 receptor and hosting SARS-CoV-like coronavirus (Mohamadian et al. 2021). 
$\mathrm{ACE} 2$, a host receptor, is responsible for entry of $\mathrm{CoV}$ into host cells. S-like protein moored with viral envelop further forms the RBD. The RBD is responsible for particular host receptor recognition and fusion of viral particle into host membrane (Li et al. 2003; Li 2015, 2016). Host susceptibility is characterized by the affinity of RBD and against ACE2 (Ghosh et al. 2009). Clitoria ternatea L. (Aparajita), widely mentioned in various Ayurveda classics, has been reported to possess metalloproteinase inhibitory activity (Maity et al. 2012) which is associated with ACE shredding, hence can be further explored for its activity on ACE2.

Virus-host cell interaction is a vital part of pathogenesis in a viral infection like COVID-19. Future studies can be postulated on the hypothesis that SARS-CoV-2 may use proteases similar to SARS-CoV like TMPRSS11a, trypsin, plasmin, cathepsin $\mathrm{L}$ and furin in the cleavage of the $\mathrm{S}$ protein for the entry of the virus into the cell (Vellingiri et al. 2020). These proteases help in propagation of virus, and the proteolytic maturation of SARS-CoV-2 depends on the CoV 3CL hydrolase (Mpro) enzyme. Efforts are also in process to take a lead from this for the production of vaccine against SAR-CoV-2 (Jakhar et al. 2020). Several studies to identify potent inhibitors of the host enzyme TMPRSS2 are also underway (Hoffmann et al. 2020). Furthermore, these proteases can be explored as targets to reduce the symptoms of COVID-19 (Millet and Whittaker 2015).

Herbs with potential effect on virus receptors or their target sites or interfering viral replication process can be used as antiviral apart from being potent immune enhancers or modulators. Plant-based traditional medicines are in use since ages. There are enough evidences of traditional medicines being used to treat the viral infection through enhancing the immunity of the body (Vimalanathan et al. 2009; Lin et al. 2014; Ganjhu et al. 2015). Plants as a whole and through variety of metabolites are useful for therapeutic purposes, for instance, cessation of viral proliferations by regulating its adsorption, binding to host cell receptors, inhibition of fusion of virus into the host cell membrane and modulating intracellular signals (Khan et al. 2005; Ghosh et al. 2009). Similarly, the binding interaction between a pathogen protein and ligand derived from herbal extracts may result in inhibition of the activity of pathogen protein (Hiremath et al. 2021). Various in silico studies were conducted (Narkhede et al. 2020; Pandit and Latha 2020; Srivastav et al. 2020; Joshi et al. 2020) for certain Rasayana herbs to explore their potential targets as mentioned in Table 1.

\section{Antiviral and immunomodulatory activities of Rasayana herbs}

Ayurveda has been used for centuries to deal with different viral diseases through various immunomodulatory herbs.
Quest for specific treatment of $\mathrm{nCoV}$ infections is a challenge with changing strain of virus rapidly. The rapid increase of persistent emerging new viral infections like COVID-19 poses a tremendous threat to mankind globally. Effective strategies for prophylaxis and holistic management are of paramount importance. In the current understanding of the pandemic, it is well known that immunity has a pivotal role in prevention of the severity of such infections. Thus, maintaining good immunity should be taken as a potential alternative for addressing such viral infection outbreaks (Hegde et al. 2009; Rijckborst et al. 2011). Herbs, which affect the immune system in specific or non-specific mode, can be categorized under immuno-herbs that are covered under the broad umbrella of Rasayana in Ayurveda (Doshi et al. 2013). These are being studied to deal with vast array of ailments like infections, nonspecific fevers (van der Meijden 2001) and immune deficiency conditions (Ziauddin et al. 1996). Here, we describe the potential role of the shortlisted Rasayana herbs against COVID-19.

\section{Justicia adhatoda L. (Adhatoda vasica Nees) (Vasa)}

Adhatoda vasica is well known for its effectiveness in respiratory disorders, particularly bronchitis and antitussive effect in Ayurveda (Dhuley 1999; Shrivastava et al. 2006). The alcoholic extract of $A$. vasica is reported to reduce the count of neutrophils, thus diminishing the phagocytosis activity. The extract was found responsible to decrease in delayed-type hypersensitivity reactions and inhibitory effect on $\mathrm{T}$ lymphocytes and also reported to possess human immunodeficiency virus (HIV) protease inhibitory activity (Singh et al. 2010; Vinothapooshan and Sundar 2011).

The oral administration of aqueous extract in allergic and severe asthmatic subtypes mouse model reports that $A$. vasica reduces increased airway resistance and alleviates steroid (dexamethasone) resistance molecular signatures. These include IL-17A, KC (murine IL-8 homologue) and hypoxiainducible factor-1 (HIF-1) by restoring expression of its negative regulator-prolyl hydroxylase domain-2 (PHD2) (Gheware et al. 2021b). In vivo studies showed that increased transforming growth factor (TGF)-1, IL-6 and HIF-1 in pulmonary fibrosis and sepsis rescues siRNA-induced inflammation and modifies cellular hypoxic response and thrombosis (Gheware et al. 2021a). These studies figured out the potential role of $A$. vasica in inflammatory situations led in SARSCoV-2 and suggest a possible role in severe steroid-resistant asthma. The potential role of $A$. vasica is also supported by recent in silico studies. Various phytoconstituents of $A$. vasica reported higher negative binding affinity for $\mathrm{C}$ - and $\mathrm{O}$ glycosides for HIF-1 $\alpha$, IL-6, Janus kinase $1 / 3$, TNF- $\alpha$ and TGF- $\beta$ key players of hypoxia inflammation diverse respiratory ailments. It was also found that vasicine possessed inhibitory activity on 3 CL protease (Thangaraju et al. 2021). 
Table 1 Potential targets and Rasayana herbs along with their phytoconstituents evaluated through various in silico studies

\begin{tabular}{|c|c|c|c|}
\hline Potential target & Phytoconstituents & Herbs & Reference \\
\hline \multirow[t]{5}{*}{3 CL protease } & Vasicine & Adhatoda vasica Nees. (Vasa) & Thangaraju et al. (2021) \\
\hline & Various phytoconstituents & Terminalia chebula Retz. (Haritaki) & Upadhyay et al. (2020) \\
\hline & Curcumin & Curcuma longa L. (Haridra) & Vajragupta et al. (2005) \\
\hline & Berberine & Tinospora cordifolia (Thunb.) Miers. (Guduchi) & Chowdhury (2020); Shree et al. (2020) \\
\hline & Withanolide I & Withania somnifera (L.) Dunal (Ashwagandha) & Khanal et al. (2021) \\
\hline Pl pro & Withanolide G & Withania somnifera (L.) Dunal (Ashwagandha) & Khanal et al. (2021) \\
\hline Inhibiting the enzyme activity of TMPRSS2 & Phyllaemblicin G7 & Phyllanthus emblica L. (Aamlaki) & Ilona et al. (2011) \\
\hline \multirow{7}{*}{$\begin{array}{l}\text { High binding affinity to ACE2 protein } \\
\text { and main protease (MPro) }\end{array}$} & Phyllaemblicin G7 & Phyllanthus emblica L. (Aamlaki) & Kothandan et al. (2021) \\
\hline & Piperolactam A & Piper longum L. (Pippali) & Kothandan et al. (2021) \\
\hline & Anisotine & Adhatoda vasica Nees. (Vasa) & Ghosh et al. (2021) \\
\hline & Embelin & Embelia ribes Burm. (Vidang) & Caruso et al. (2020) \\
\hline & Withaferin A & Withania somnifera (L.) Dunal (Ashwagandha) & Straughn and Kakar (2020) \\
\hline & Cordioside and other constituents & Tinospora cordifolia (Thunb.) Miers. (Guduchi) & Jena et al. (2021) \\
\hline & Glycyrrhizin & Glycyrrhiza glabra L. (Yastimadhu) & Muhseen et al. (2021) \\
\hline \multirow[t]{3}{*}{ Mpro } & Boeravisterol & Boerhavia diffusa L (Punarnava) & Rutwick Surya and Praveen (2021) \\
\hline & Embelin & Embelia ribes Burm. (Vidang) & Caruso et al. (2020) \\
\hline & Various phytoconstituents & Tinospora cordifolia (Thunb.) Miers. (Guduchi) & Shree et al. (2020) \\
\hline \multirow[t]{2}{*}{ Nsp 15 endoribonuclease } & Glyasperin & Glycyrrhiza glabra L. (Yashtimadhu) & Muhseen et al. (2020) \\
\hline & Asparoside-D & Asparagus racemosus Willd. (Shatavari) & Chikhale et al. (2020) \\
\hline \multirow[t]{4}{*}{ ACE2-RBD interface } & Withanone & Withania somnifera L. Dunal (Ashwagandha) & Balkrishna et al. (2020b); Muhseen et al. (2020) \\
\hline & Withanolide A & & \\
\hline & Glyasperin & & \\
\hline & Glycyrrhyzin & Glycyrrhiza glabra L. (Yashtimadhu) & Muhseen et al. (2020) \\
\hline RBD complex & Glycyrrhizinate complex & Glycyrrhiza glabra L. (Yashtimadhu) & Kalhor et al. (2020) \\
\hline \multirow[t]{5}{*}{ Spike protein } & Phyllaemblicin G7 & Phyllanthus emblica L. (Aamlaki) & Ilona et al. (2011) \\
\hline & $\begin{array}{l}\text { Racemoside } \mathrm{A} \text {, racemoside } \\
\quad \mathrm{C} \text {, asparoside-C, asparoside- } \mathrm{F}\end{array}$ & Asparagus racemosus Willd. (Shatavari) & Chikhale et al. (2020); Patel et al. (2021) \\
\hline & Glycyrrhizic acid & Glycyrrhiza glabra L. (Yashtimadhu) & Sinha et al. (2020) \\
\hline & Withaferin & Withania somnifera (L.) Dunal (Ashwagandha) & Straughn and Kakar (2020) \\
\hline & Withanolide M & Withania somnifera (L.) Dunal (Ashwagandha) & Khanal et al. (2021) \\
\hline Helicase inhibitors & $\begin{array}{l}\text { Phyllaemblicin B } \\
\text { Phyllaemblinol }\end{array}$ & Phyllanthus emblica L. (Aamlaki) & Ilona et al. (2011) \\
\hline
\end{tabular}

Another alkaloid anisotine has also shown inhibitory effect on the proteolytic activity of Mpro in docking studies (Ghosh et al. 2021). In another study, anisotine and vasicoline of $A$. vasica were found effective as protease and replicase inhibitor of COVID-19 virus using COVID-19 docking server (Bag and Bag 2020).

\section{Asparagus racemosus Willd. (Shatavari)}

Asparagus racemosus is commonly used galactagogue in Ayurveda (Alok et al. 2013). Various pharmacological activities of A. racemosus include anti-inflammatory, antioxidant, immunomodulatory, immunoadjuvant and adaptogenic activity (Bopana and Saxena 2007; Alok et al. 2013). The aqueous extract of A. racemosus showed significant increase of CD3(+ ) and CD4/CD8(+). This effect is proposing its effect on T cell activation (Gautam et al. 2009). There was an upregulation of Th 1, IL-2, interferon gamma (IFN- $\gamma$ ) and Th2 (IL-4) cytokines proposing its blended Th1/Th2 adjuvant action. Higher antibody titres and delayed-type hypersensitivity (DTH) responses were also reported along with the effect on activated lymphocytes (Sabde et al. 2011). The herb was also evaluated against anti-HIV activity in a human CD4+ T cell line, a stable
$\mathrm{T}$ cell line $(\mathrm{CEM})$ - green fluorescent protein cells infected with HIV-1NL4 - and the extract was found to possess reduction of viral production in CEM-GFP cells infected with HIV1NL4 (Dhar et al. 1968).

A recent in silico study was conducted to explore the effect of A. racemosus in COVID-19 (Chikhale et al. 2020). The prime specialized metabolites of the plant asparoside-C, asparoside-D and asparoside-F were evaluated against NSP15 endoribonuclease and S RBD. The study revealed that asparoside- $\mathrm{C}$, asparoside-D and asparoside- $\mathrm{F}$ exhibited their potential effect against both the proteins and reported to have substantial effect against SARS-CoV-2. In another in silico study, natural steroidal saponins racemoside $\mathrm{A}$ and racemoside $\mathrm{C}$ interact with RBD of S-protein and inhibit its interaction with ACE2, ultimately blocking the entry of viral particle into the human host. It interact with S-protein and other structural proteins of SARS-CoV-2 (Patel et al. 2021). As far as the toxicity is concerned, the aqueous extract of the roots of A. racemosus has been reported for diuretic activity at the highest dose of $3200 \mathrm{mg} / \mathrm{kg}$ without any acute toxicity (Kumar et al. 2010). However, it does not reported mortality at the oral dosage of $64 \mathrm{~g} / \mathrm{kg}$ in an earlier study (Goyal et al. 2003). 


\section{Boerhavia diffusa L. (Punarnava)}

B. diffusa is reported for anti-inflammatory, immunosuppressive and antioxidant properties (Mishra et al. 2014). The compound eupalitin-3-O-beta-D-galactopyranoside (Bd-I) found in $B$. diffusa is reported for inhibition of the production of phytohemagglutinin (PHA) which stimulated IL-2 at the protein and mRNA transcript levels and lipopolysaccharide (LPS) which stimulated TNF- $\alpha$ production in human peripheral blood mononuclear cell (PBMC). The activation of DNA binding of NF-kB and activator protein 1 (AP-1), two major transcription factors which are involved in the expression of IL-2 and $I L-2 R$ gene, which is necessary for T cell activation and proliferation are also blocked by Bd-I (Manu and Kuttan 2007). Punarnavine, another compound found in $B$. diffusa, is reported to enhance the immune responses against the metastatic progression by promoting the cell-mediated immune responses. It enhances the NK cell activity and production of cytokines such as IL-2 and IFN- $\gamma$ and lowers the peaks of IL$1 \beta$, IL-6 and TNF- $\alpha$ (Bose et al. 2017). Boeravinone $\mathrm{H}$ is a potential antiviral agent for the prevention and control of hepatitis $\mathrm{C}$ virus (HCV) infection. It acts by inhibiting the initial phase of $\mathrm{HCV}$ entry binding and entry of hepatitis C-like particles (HCV-LPs) in hepatoma cells in vitro. The prevention of HCV entry and infection in cell culture was also reported in ex vivo studies (Hossan et al. 2018). In addition, the plant is also reported for a potent anti-HIV compound and in Ranikhet disease virus (Pandey et al. 2005). In an in silico study, the compound boeravisterol found in $B$. diffusa was evaluated against Mpro and was found to have therapeutic properties against COVID-19 (Rutwick Surya and Praveen 2021). Further, no acute and sub-acute toxicity was reported from B. diffusa root extract at the dose of $200 \mathrm{mg} / \mathrm{kg}$ in Wistar rats (Karwasra et al. 2016).

\section{Curcuma longa L. (Haridra)}

C. longa is among the most commonly used drug in Ayurveda, a common spice (Thimmulappa et al. 2021) and colouring agent ( $\mathrm{Ou}$ et al. 2013). Curcumin, one of the main active principle of C. longa ( $\mathrm{Li}$ et al. 2019), is reported to inhibit NF- $\mathrm{KB}$ activation post exposure of various inflammatory stimuli in 117 randomized control trials. There was a significant reduction in TNF- $\alpha$, IL-6, TGF- $\beta$ and MCP- 1 following curcumin supplementation (Panahi et al. 2016). Curcumin inhibits mitogen-stimulated lymphocyte proliferation, IL-2 synthesis/signaling and NF-kB (IL-2 promoter transcription factor) activation (Ranjan et al. 2004). Additionally, the macrophage phagocytic activity is also increased by curcumin (Antony et al. 1999).

A study exhibited that nanoparticulate curcumin stimulated higher early cell-mediated and humoral immune response with similar results in secondary humoral antibody titres.
Production of white blood cells and weight of the lymphoid organs were also enhanced in the groups that received 10 $\mathrm{mg} / \mathrm{kg}$ nanocurcumin (Afolayan et al. 2018). Curcumin has been reported effective against many enveloped viruses, including respiratory viruses like influenza $\mathrm{A}$ and respiratory syncytial virus (Praditya et al. 2019). Curcumin may interfere the entry of type A influenza virus by its interaction with the receptor binding region or interfering with viral haemagglutination protein (Ou et al. 2013). The monoacetylcurcumin, a structural analogue of curcumin on Akt phosphorylation, is needed for propagation of influenza A virus (Richart et al. 2018). An in vitro study of curcumin reported capability to inhibit gene replication of hepatitis B virus (HBV) by inhibiting cccDNA-bound histone acetylation, and it has the potential to be developed as a cccDNAtargeting antiviral agent for hepatitis B (Wei et al. 2017). Furthermore, a study reported that curcumin inhibits $3 \mathrm{CL}$ protease activity in SARS-CoV, an essential composition for viral replication (Wen et al. 2007). Taking leads from earlier studies, a recent docking study on SARS-CoV-2 reports the potential of curcumin in inhibiting SARS-CoV-2 into lung cells by disrupting the interaction of $\mathrm{S}$ protein and ACE2 (Rajagopal et al. 2020; Pandey et al. 2020). This shows the potential of curcumin in the disruption of SARS-CoV-2 virus entry and replication which is also associated with the activation of the nuclear factor erythroid 2-related factor 2 (NRF2) pathway (Thimmulappa et al. 2021). C. longa and its phytoconstituents are found to be safe in various clinical studies (Tønnesen et al. 2002; Maheshwari et al. 2006; Aggarwal et al. 2016; Thimmulappa et al. 2021).

\section{Embelia ribes Burm. (Vidang)}

E. ribes is a commonly used anthelmintic traditional remedy (Bhandari et al. 2002). It is reported to have antimicrobial, antidiabetic, antioxidant, anti-inflammatory, analgesic, contraceptive and antipsychotic activity and also used in acute respiratory distress syndrome (Bhandari et al. 2002; Harish et al. 2012; Shirole et al. 2015; Durg et al. 2017). Embelin, the major phytoconstituent of $E$. ribes, was examined in an in silico molecular docking study. The study showed that the binding site for embelin is located in the RBD of viral haemagglutinin which can be utilized for the development of a plant-based anti-influenza agent (Bachmetov et al. 2012). Another important polyphenol present in the plant is quercetin. It is reported for diverse antiviral activities against influenza virus (H1N1) and HCV. Quercetin inhibits the HCV NS3 protease and reduces viral production by inhibiting both NS3 and heat shock proteins which are essential for HCV replication (Bachmetov et al. 2012). Quercetin is reported for viral step inhibition of internal ribosome entry site translation, NS5A protein levels, HCV replication, $\mathrm{HCV}$ production and putative viral target-NS3 protease (Gonzalez et al. 2009; 
Shirole et al. 2015). Further, in a study, ethyl acetate extract of fruits of $E$. ribes has shown very promising antiviral activity against influenza virus A/34 (H1N1), with an IC50 of $0.2 \mu \mathrm{g} /$ $\mathrm{mL}$; also, the study revealed that embelin was most effective when added at early stages of the viral life cycle $(0-1 \mathrm{~h}$ postinfection), and also, it was found effective against avian influenza virus A/84 (H5N2) (Bachmetov et al. 2012).

A study has reported that pre-treatment with embelin $(5,10$ and $20 \mathrm{mg} / \mathrm{kg}$, i.p.) decreased lung oedema, mononucleated cellular infiltration, nitrate/nitrite, total protein, albumin concentrations, TNF- $\alpha$ in the bronchoalveolar lavage fluid and myeloperoxidase activity in lung homogenate. Embelin markedly prevented $\mathrm{pO} 2$ down-regulation and $\mathrm{pCO} 2$ augmentation. Additionally, it attenuated lung histopathological changes in acute respiratory distress syndrome model, thus exhibiting lung protecting property and anti-inflammatory activity in lung cell. hence can be a promising herb in preventing lung damage like complications in COVID-19 (Hossan et al. 2018). A recent computational study reports the role of embelin to inhibit the SARS-CoV-2 Mpro protease more specifically due to formation of a covalent bond between $\mathrm{S}$ (Cys145) and an embelin C (carbonyl). This is further assisted by two protein amino acids $\mathrm{N}$ (imidazole-His41) which are able to capture $\mathrm{H}[\mathrm{S}(\mathrm{Cys} 145)]$ and $\mathrm{HN}$ (His163), which donate a proton to embelin $\mathrm{O}$ (carbonyl) forming an $\mathrm{OH}$ moiety. This results in inhibition of the viral protease (Caruso et al. 2020). Ayurvedic literature mainly counts the fruits of $E$. ribes for its effect as antibacterial, antiprotozoal, analgesic, anti-inflammatory, antioxidant and treatment for abdominal disorders and lung fungus infections (Dwivedi et al. 2019). This drug has been reported for the treatment of influenza in 1919 (Menon 1919). Respiratory distress is one of the major symptoms found during the second surge of SARS-CoV-2 in India. E. ribes also possesses anti-inflammatory and protective effect against LPS-induced airway inflammation by reducing nitrosative stress, physiological parameters of blood gas change, TNF and mononucleated cellular infiltration, indicating it as a potential therapeutic agent for acute respiratory distress syndrome (Shirole et al. 2015). The drug can be repurposed for the respiratory distress happening in SARS-CoV-2.

Potassium embelate, 2,5-dihydroxy, 3-undecyl-1, 4-benzoquinone, derived from $E$. ribes was tested for subacute, chronic, reproductive toxicity and teratological studies in laboratory animals (mice, rats and monkeys), showing this as a safe compound (Johri et al. 1990). However, embelin was found to reduce sperm count at a dose of $20 \mathrm{mg} / \mathrm{kg}$ body weight to male albino rats for 15 or 30 days (Gupta et al. 1989). Dosedependent visual deficits were also observed in chicks by embelin (Low et al. 1985), and 6 weeks consumption resulted in severe pathological changes in the liver and kidney, such as disintegration, necrosis and perinuclear vacuolation (Harish et al. 2012).

\section{Glycyrrhiza glabra L. (Yastimadhu)}

G. glabra has been reported for anti-oxidant, anti-inflammatory, immunomodulator, antiviral, antipyretic, antidemulcent and antitussive activity (Shah et al. 2018; Sharma et al. 2018; El-Saber Batiha et al. 2020). Glycyrrhizin, the main active constituent of the plant, is reported to interfere with immune responses by targeting dendritic cells. It also upregulate the expression of CD40, CD86 and MHC-II maturation markers on dendritic cells as well as enhances the production of IL-12 by these cells. It also increases the IFN- $\gamma$ and IL-10 and further reduces IL-4 production (Bordbar et al. 2012). Glycyrrhizin treatment increased antioxidant status, decreased the incidence of free radical-induced lipid peroxidation and improved immunity activities in the nasal and blood mucosa of allergic rhinitis mice ( $\mathrm{Li}$ et al. 2011). The root extract of G. glabra in association with zinc has also shown immunomodulatory activity (Mitra Mazumder et al. 2012). G. glabra has shown promising result in targeting the viral replication of SARS-CoV; thus it is a potential herb for further study on SARS-CoV-2 (Cinatl et al. 2003). Glycyrrhizin is also reported to inhibit SARS-CoV replication in vitro (Hoever et al. 2005). Licorice and glycyrrhizin are reported to inhibit the plaque formation in three strains of Japanese encephalitis virus (Badam 1997). Glycyrrhizin and its other derivatives reduce the hepatocellular damage in chronic hepatitis B (Sato et al. 1996). Similarly, glycyrrhizin reduces the levels of transaminase in chronic hepatitis $\mathrm{C}$ in phase II randomized trials (Orlent et al. 2006; Fiore et al. 2008). The mechanism behind the antiviral activity of various species of Glycyrrhiza includes reduced transport to the membrane and sialylation of HBV surface antigen, reduced membrane fluidity leading to inhibition of fusion of the viral membrane of HIV1 with the cell, induction of IFN- $\gamma$ in T cells, inhibition of phosphorylating enzymes in vesicular stomatitis virus infection and reduction of viral latency (Fiore et al. 2008).

The in vitro studies reported the inhibition of growth of several DNA and RNA viruses by glycyrrhizic acid and also reported the inactivation of herpes simplex viruses (HSV-1) irreversibly (Pompei et al. 1980). Glycyrrhizin inhibits the viral replication in H5N1 influenza (Michaelis et al. 2011) and in SARS-CoV too (Cinatl et al. 2003). Glycyrrhizin may act against viruses via a variety of mechanisms, including increasing nitrous oxide production in macrophages, influencing transcription factors and cellular signaling pathways, directly altering the viral lipid-bilayer membrane and binding to the ACE2 receptor (Chrzanowski et al. 2021). This may provide two-pronged approach to reduce the severity of SARSCoV-2 infection by blocking the number of entry points and initiating the ACE2-independent anti-inflammatory mechanism (Murck 2020). G. glabra extracts and glycyrrhizin possess significant antioxidant, anti-inflammatory and immunomodulatory effects and may bind to viral fusion proteins, 
preventing viral entry into host cells, as well as increasing ACE2 expression (Gomaa and Abdel-Wadood 2021). Glycyrrhizic acid inhibits the growth of the virus and inactivates virus particles. Thus, glycyrrhizic acid is a potential source of immunomodulatory effect (Arora et al. 2011). A structure-based virtual screening followed by molecular dynamics (MD) simulation and binding energy analysis was used to identify specific terpenes from medicinal plants that can block SARS-CoV-2 S-RBD binding to human ACE2 and act as potent anti-COVID-19 drugs (Muhseen et al. 2020). An in silico study found that glyasperin A had a high affinity for Nsp15 endoribonuclease with uridine specificity, whereas glycyrrhizic acid was best suited for the binding pocket of S glycoprotein and also prevented virus entry into the host cell (Sinha et al. 2020). N nonpolar licorice extract of G. uralensis reports no acute and chronic toxicity (Kim et al. 2020a). Glycyrrhizin is majorly used as flavouring agent and listed its use in food without restrictions. Glycyrrhyzic acid ammoniated is safe for all species at a concentration of $1 \mathrm{mg} / \mathrm{kg}$ complete feed, except chickens for fattening and laying hens. A safe concentration of $0.3 \mathrm{mg} / \mathrm{kg}$ complete feed applies to these two categories ((FEEDAP) EP on A and P or S used in AF 2015). However, a study reports use of G. glabra and glycyrrhizin salts with caution during pregnancy and selective cytotoxic effects on cancerous cells (Nazari et al. 2017).

\section{Phyllanthus emblica L. (Emblica officinalis) (Aamlaki)}

P. emblica is reported for anti-inflammatory, antioxidant, immunomodulatory, antimalarial, antimicrobial, anticancer, antidiabetic, hypolipidemic, antioxidant, hepatoprotective, nephroprotective and diuretic properties (Patel et al. 2011; Lee et al. 2016; George et al. 2019a; Harikrishnan et al. 2020). P. emblica is reported to enhance NK cell activity and antibody-dependent cellular cytotoxicity in syngeneic BALB/c mice (Suresh and Vasudevan 1994). The fruit extracts are reported to restore the IL-2 and gamma-IFN production (Sai Ram et al. 2002) and decrease the levels of lipid peroxidation, reactive oxygen species (ROS) production, the activity of caspase-3, apoptosis and increased cell viability, levels of antioxidant enzymes, cytochrome c oxidase and mitochondrial membrane potential (Singh et al. 2013). It exhibited cytoprotective effects and lowered ROS levels in cells subjected to t-BHP-induced oxidative stress (Yamamoto et al. 2016). Further, it also stimulates the reticuloendothelial system and activates the polymorphonuclear and monocyte-macrophase system (Thatte and Dahanukar 1997).

An in vitro study was conducted on E. officinalis extracts in IB3-1 CF bronchial epithelial cells exposed to the pseudomonas aeruginosa laboratory strain PAO1. Pyrogallol found in E. officinalis extract inhibits the neutrophil chemokines IL-8, growth-related oncogene (GRO)-alpha, GRO-gamma, the intercellular adhesion molecule (ICAM-1) and IL-6 (Nicolis et al. 2008). E. officinalis stimulates humoral and cellmediated immunity along with macrophage phagocyte (Suja et al. 2009). In silico studies have shown that piceatannol and phyllaemblicin G7 present in P. emblica have a high affinity for spike protein and also inhibit the enzyme activity of TMPRSS2 which cuts the spike protein helping to trigger SARS-CoV and MERS-CoV and has a high binding affinity to ACE2 protein. Phyllaemblicin B and phyllaemblinol present in it have a good affinity towards helicase inhibitors (it is a multi-functional protein, including N-terminal metal binding domain (MBD) and helicase domain (Hel); it is reported to be a necessary component for the replication of coronavirus) (Ilona et al. 2011). The acute toxicity at $5000 \mathrm{ml}$ and chronic oral toxicities $(300,600$ and $1200 \mathrm{mg} / \mathrm{kg}$ ) were evaluated in rats, and it is reported safe (Jaijoy et al. 2010b). Another study also reports the no acute and chronic toxicity by $P$. emblica (Jaijoy et al. 2010a; Huabprasert et al. 2012).

\section{Phyllanthus amarus Schum. (Bhumi amalaki)}

Phyllanthus amarus is commonly used for kidney, liver and genitourinary tract disorders in Ayurveda (Patel et al. 2011). It is also reported for its antiviral, anti-inflammatory and antioxidant activities (Joseph and Raj 2011; Sarin et al. 2014). Phyllanthus amarus has anticancer and anti-inflammatory effects by disrupting the NF-kB, mitogen activated protein kinase (MAPKs), phosphatidylinositol 3-kinase/Akt (PI3K/Akt) and Wnt signaling networks (Harikrishnan et al. 2020). P. amarus specifically reported to inhibit NF-KB (Ismail et al. 2020). The NF-KB signaling pathway connects pathogenic and cellular danger signals, thus providing cellular resistance to invading pathogens. This is considered as an innate immunity regulator (Albensi 2019). Phyllanthin found in P. amarus inhibits cellular and humoral immune response in Balb/C mice (Ilangkovan et al. 2016). Ethanolic extract of $P$. amarus has targeted the NF-KB, MAPK and PI3K-Akt signaling pathways to exert its anti-inflammatory effects by down-regulating the prospective inflammatory signaling mediators (Harikrishnan et al. 2018). Another in vitro study reported that hairy roots of $P$. amarus have shown inactivation of HBV surface antigen (Mehrotra et al. 1991). Aqueous extract of $P$. amarus showed antiviral activity against white spot syndrome virus (Balasubramanian et al. 2007). Viral enzymes NS3 protease and NS5B RNA-dependent RNA polymerase are required for polyprotein processing and viral RNA replication and can be potential targets for anti-HCV compound screening. An in vitro study of $P$. amarus root extract is reported for inhibition of HCV-NS3 protease enzyme, and $P$. amarus leaves extract showed inhibition of NS5B (Ravikumar et al. 2011). There is a structural similarity of NS3 protease and SARS-CoV-2 (Bafna et al. 2020) particularly in the key active site residues. $P$ amarus and E. ribes are known to have activity against HCV NS3/4A protease. These 
may be repurposed for the treatment of COVID-19 (Mandal et al. 2021). A recent in silico docking analysis reports the potential of various phytochemicals of $P$. amarus may have action on multiple target sites of SARS-CoV-2 (Hiremath et al. 2021). Many formulations of $P$. amarus are found to be safe in clinical trials as well (Ajala et al. 2016; George et al. 2019b). In a toxicity study, extracts of $P$. amarus were found to be safe in mice and rats (Lawson-Evi et al. 2008).

\section{Piper longum L. (Pippali)}

Piper longum is majorly regarded as immunomodulatory, anti-inflammatory, antioxidant, bioavailability enhancer, hepatoprotective, analgesic, antiplatelet and antifungal agent (Kumar et al. 2011; Yadav et al. 2020). The $4 \alpha$ dihydroxy1-(3-phenyl propanoyl)-piperidine-2 compound found in $P$. longum is reported to reduce the passive cutaneous anaphylaxis in rats and protected guinea pigs against antigen-induced bronchospasm (Kulshreshta et al. 1969). The chloroform extract of $P$. longum inhibits ICAM-1, vascular cell adhesion protein 1 and E-selectin via the inhibition of NF-kB in endothelial cells. This also inhibited NADPH-catalysed rat liver microsomal lipid peroxidation, demonstrating its antioxidant activity (Singh et al. 2008). These findings point towards antiinflammatory and antioxidant activity of $P$. longum (Reddy and Lokesh 1992). P. longum is also reported to activate cellular and humoral immune responses (Sunila and Kuttan 2004). It also exhibits good bioavailability enhancer properties (Kesarwani et al. 2013). In vitro studies of piperine reported for significant inhibitory HBV activity against the secretion of HBV surface antigen (HBsAg) and HBV e antigen (HBeAg) (Jiang et al. 2013). Piperolactam A, another phytoconstituent of $P$. longum, was found to be an effective inhibitor of S-protein binding to the GRP78 receptor which can prevent the virus from binding to the host by preventing the S-protein from binding to the CS-GRP78 cell surface receptor in an in silico study (Kothandan et al. 2021).

Many clinical studies on P. longum have been conducted, and the herb has been found to be safe (Manoj et al. 2004; Pathak et al. 2010). A randomized, pen label exploratory trial is registered in India for the evaluation of safety and efficacy of $T$. cordifolia $+P$. longum as adjunct treatment to standard care for the management of mild to moderate COVID-19 patients (CTRI/2020/06/025557). A similar kind of randomized double-blind placebo-controlled trial to evaluate the effect of curcumin-piperine in SARS-CoV-2 patients in Iran is also ongoing (Miryan et al. 2020). Acute toxicity studies of $P$. longum show no mortality or morbidity when 3 to $5 \mathrm{~g} / \mathrm{kg}$ is administered to animals during pharmacological studies; however, under certain conditions, such as pregnancy and lactation, the fruits of $P$. longum should be used with caution due to potential interactions (Chanda et al. 2009).

\section{Stereospermum suaveolens DC. (Patla)}

Stereospermum suaveolens is mainly indicated as analgesic, liver stimulant, astringent, wound healing and antidyspeptic in Ayurveda (Wahab Sab et al. 2015). It has been reported for anti-inflammatory, immunomodulatory, anti-arthritic, antioxidant and antidiabetic (Balasubramanian et al. 2012; Latha et al. 2020). The root extract is reported to increase the total leukocyte count and the population of monocyte and neutrophil in experimental studies. Immunostimulatory potential is reported via DTH response, phagocytic activity and intracellular killing potential of phagocytes (Maji et al. 2014). S. suaveolens also reported to provide protection from Ranikhet disease virus (Bhakuni et al. 1971).

S. suaveolens is an important ingredient of Dashamoola kwath, an important Ayurvedic formulation. Dashamoola formulation, both alone and in combination with aspirin, demonstrated anti-inflammatory, analgesic and anti-platelet effects comparable to aspirin (Parekar et al. 2015). S. suaveolens is also one of the major ingredients of the decoction used in the formulation of AYUSH-64 which is officially recommended for the different categories of COVID-19 patients by the Ministry of AYUSH (Sumathi et al. 2021) and also found effective as an antiviral, anti-asthmatic and immunoboosting (Ahmad et al. 2021).

\section{Terminalia chebula Retz. (Haritaki)}

Terminalia chebula is reported for antioxidant, anti-inflammatory, antimutagenic, antimicrobial, antidiabetic, hepatoprotective, cardioprotective, antiarthritic and gastrointestinal motility (Bag et al. 2013; Manosroi et al. 2013; Afshari et al. 2016). Triphala is a polyherbal formulation comprised of T. chebula, T. bellerica and Emblica officinalis reported for stimulating neutrophil function and significantly reduces IL-4 levels and corrects decreased IL-2 and IFN levels (Belapurkar et al. 2014).

The aqueous extract of dried fruits of $T$. chebula was reported to increase humoral antibody titre and DTH in mice (Shivaprasad HN 2006). Another study also reported enhanced expression of Th1 cytokine, INF- $\gamma$; decreased IL 4; increased percentage of CD4+ cells; lymphocyte proliferation; macrophage phagocyte response; and DTH response in mice (Rubab and Ali 2016). Chebulagic and chebulinic acids are reported for antiviral activity against HSV-2 possibly due to inhibition of virus attachment and penetration to the host cells as compared to acyclovir (Kesharwani et al. 2017). Chebulagic acid and punicalagin are also reported for potent antiviral activity against HSV-1 by inhibiting viral glycoprotein interactions with cell surface glycosaminoglycans (GAGs) (Lin et al. 2011).

Further, in extended study, chebulagic acid and punicalagin are found effective in abrogating infection by 


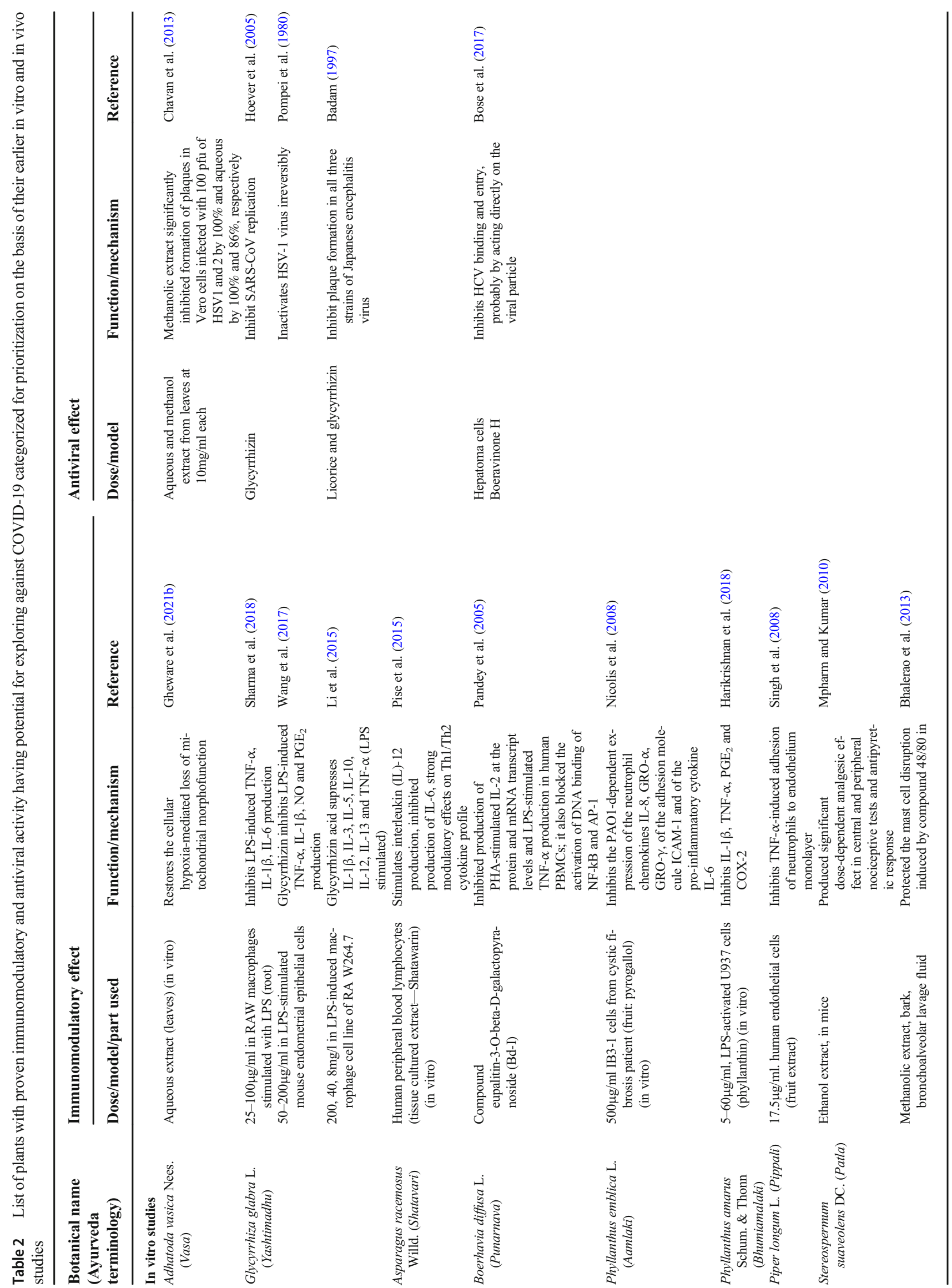




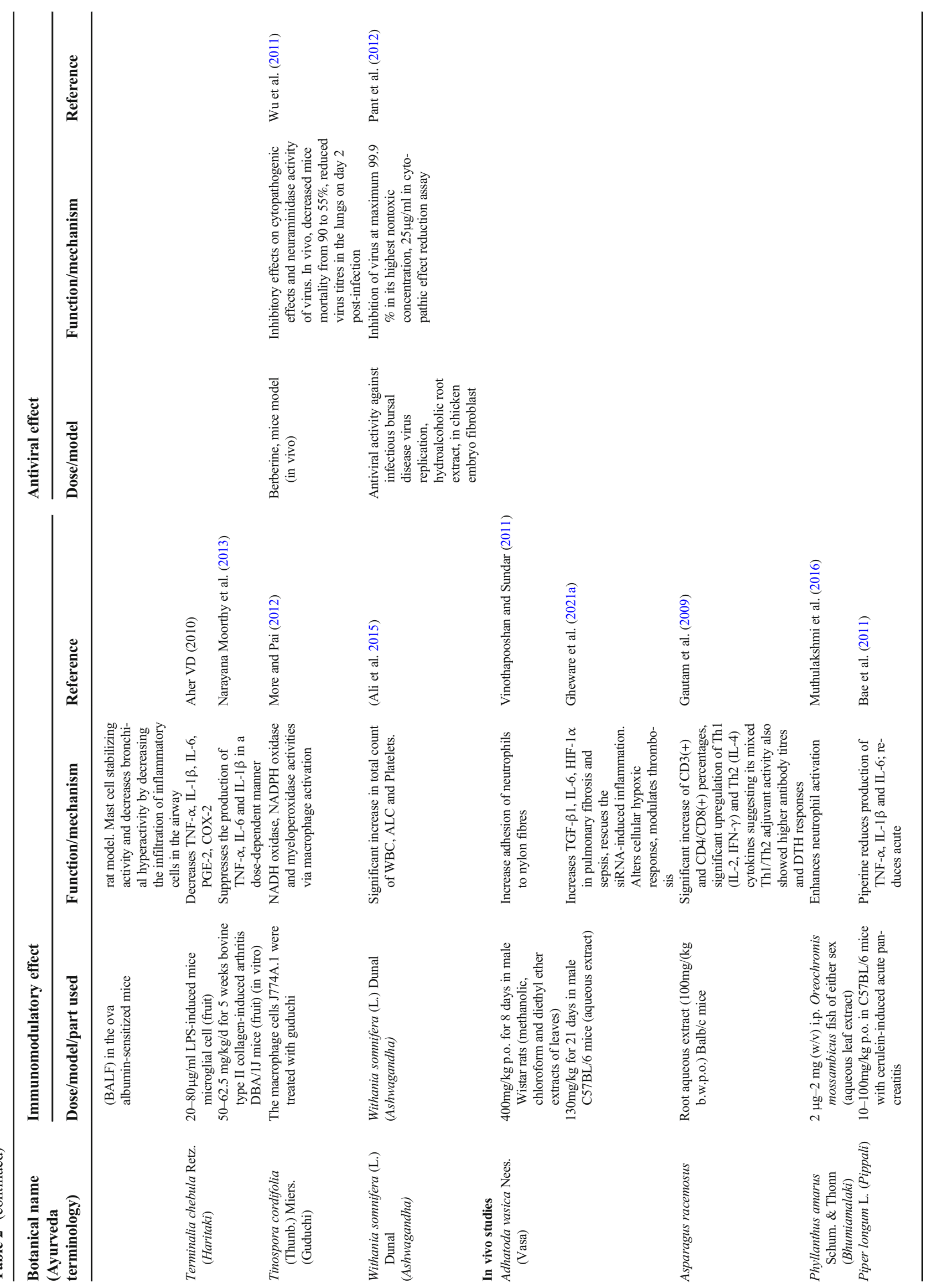




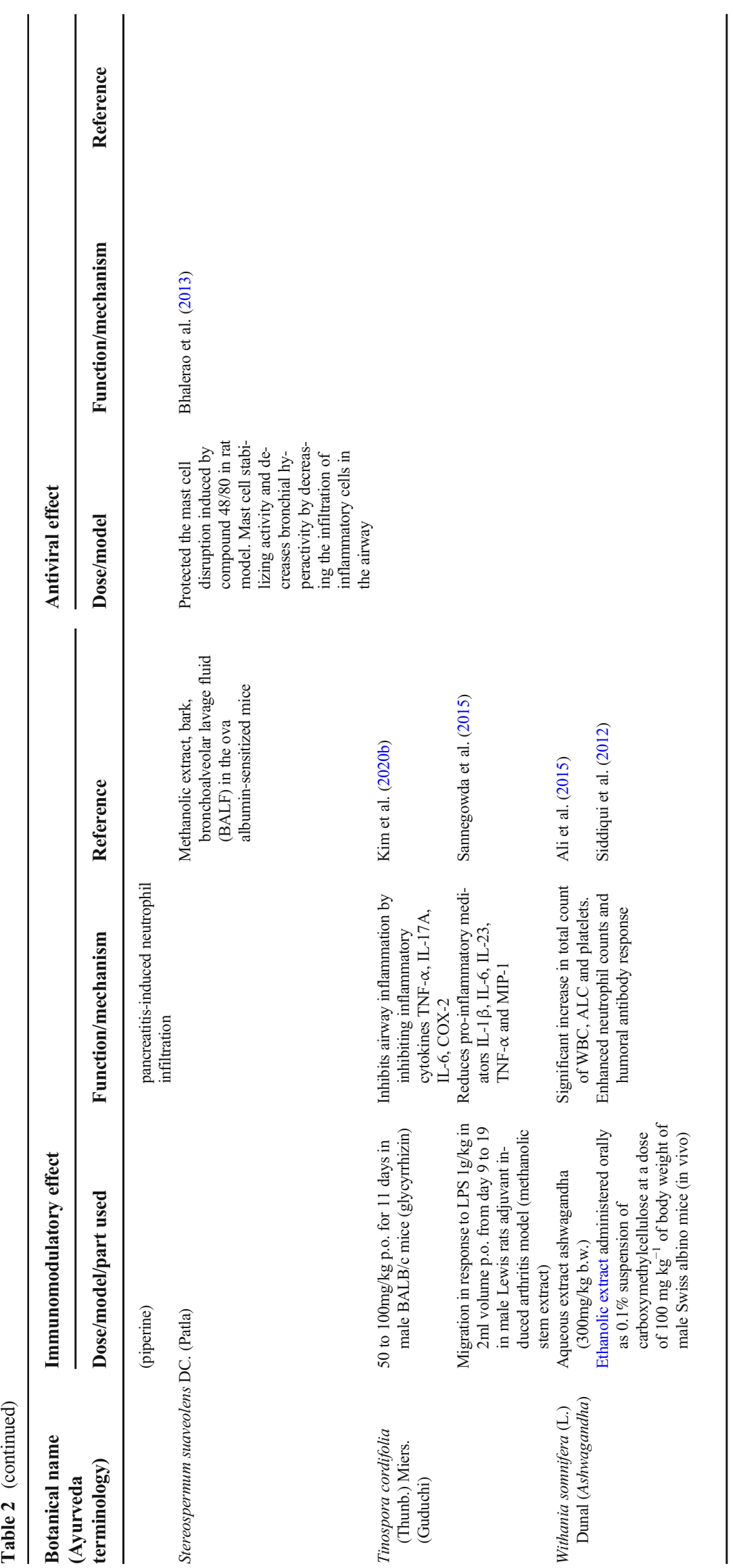


human cytomegalovirus (CMV), $\mathrm{HCV}$, dengue virus, measles virus and respiratory syncytial virus at $\mu \mathrm{M}$ concentrations. The tannin compounds, viz. chebulagic acid and punicalagin, have been reported for antiviral activity possibly mediated through inhibition of early virus entry and inactivation of free virus particles (Lin et al. 2013). The aqueous extract of T. chebula acted as potential inhibitor of $3 \mathrm{CL}^{\text {pro }}$ protease activity of SARS-CoV-2 in in silico study. The inhibition of this enzymatic activity has the potential to prevent virus replication within cells and may confer a protective effect in COVID19 (Upadhyay et al. 2020). Hot water extract of T. chebula inhibited the replication of human CMV in vitro and in an AIDS model with immunocompromised mice, and the study concluded that it could be useful in the prevention of CMV diseases and immunocompromised patients (Yukawa et al. 1996). T. chebula is reported for diverse pharmacological activities like antioxidant, antimicrobial, antidiabetic, hepatoprotective and antiproliferative (Bag et al. 2013). T. chebula has shown neither genotoxic effect nor cellular toxicity on sheep erythrocytes and acute oral toxic effects on rats (Bag et al. 2013). Furthermore, a hydroalcoholic extract of T. chebula fruits inhibited cytochrome P-450 in rats (Ponnusankar et al. 2011). The safety studies have been reported and may be repurposed for prophylactic and therapeutic effect against COVID-19.

\section{Tinospora cordifolia (Thunb.) Miers. (Guduchi)}

Tinospora cordifolia is one of the most widely used plants in Ayurveda for a wide range of diseases. Various studies reported the effect of $T$. cordifolia in increasing phagocytic, intercellular bactericidal capacity, lysozyme activity, enhanced nitro-blue tetrazolium (NBT) level, total immunoglobulin level, antiprotease activity, myelo-peroxidase activity, macrophage activation and secretion of lysozyme by macrophage cell line J774A and preventing deterioration of Kupffer cell activity (Thatte et al. 1992; Aranha et al. 2012; More and Pai 2012). It was also reported to reduce pro-inflammatory mediators IL-1 $\beta$, IL-6, IL-23, TNF- $\alpha$ and MIP-1 (Sannegowda et al. 2015). The aqueous extract of $T$. cordifolia is reported to influence the cytokine production, mitogenicity, stimulation and activation of immune effector cells. In vitro evidence also supports it by showing upregulating effect on the IL-6 cytokines facilitating the acute response to injuries, inflammation, activation of cytotoxic $\mathrm{T}$ cells and $\mathrm{B}$ cell diffraction (Sharma et al. 2012).

Berberine found in T. cordifolia inhibits the cytopathogenic effects and neuraminidase activity of influenza virus both in vitro and in vivo as well as improving pathogenic changes by suppressing the release of inflammatory substances $(\mathrm{Wu}$ et al. 2011). In addition, T. cordifolia also increases IL-2, IFN- $\gamma$, IL-4 and IL-1 $\beta$ (Sachan et al. 2019). The aqueous extract was reported to reduce the mortality rate and enhance the immunity in the young chicks infected from infectious bursal disease caused by infectious bursal disease virus. This suggests its possible use as immunomodulator in viral diseases (Sachan et al. 2019). The ethanolic leaf extract decreases the high-level intracellular ROS in the Chikungunya patients with persisting polyarthralgia (Banerjee et al. 2018). Medication like Samshamanivati, composed of aqueous extract of T. cordifolia (Kalikar et al. 2008), has been found to be effective in various types of viral infections by virtue of cellmediated immunity (Aranha et al. 2012).

T. cordifolia secondary metabolites have a high binding efficiency in inhibiting the SARS-CoV-2 main protease as reported in an in silico study (Thakkar et al. 2021). T. cordifolia also reported to inhibit main protease $\left(\mathrm{M}^{\text {pro }}\right.$ or $3 \mathrm{Cl}^{\text {pro }}$ ) of SARS-CoV-2 (Shree et al. 2020). Another docking study revealed the potential of six constituents of $T$. cordifolia in the prevention of SARS-CoV-2 S protein from binding to the human receptor ACE2 protein (Jena et al. 2021). T. cordifolia also demonstrated high binding efficacy against the targets involved in attachment and replication of the virus, as compared to favipiravir and lopinavir/ritonavir (Chowdhury 2020). In a safety study, T. cordifolia has not shown clastogenicity and DNA damage in human peripheral blood lymphocytes up to a concentration of $3000 \mu \mathrm{g} / \mathrm{ml}$ in Balb/c mice (Chandrasekaran et al. 2009; Alajmi et al. 2018) and also was found safe in clinical studies (Castillo et al. 2013).

\section{Withania somnifera (L.) Dunal (Ashwagandha)}

Withania somnifera is the most commonly used herb in Ayurveda. This is well known for its adaptogenic, immunomodulatory, anti-inflammatory, antioxidant, anti-stress, antitumorigenic, antihypertensive, antidiabetic, organ-protective, antimicrobial and antifungal activities (Dar et al. 2015; Kakar et al. 2017; Gurav et al. 2020; Saleem et al. 2020). The aqueous extract of roots of $W$. somnifera was reported to upregulate Th1-dominant polarization, thus supporting the humoral immunity and cell-mediated immune responses in BALB/c mice (Bani et al. 2006). The methanolic extract of the roots enhances the level of IFN- $\gamma$, IL-2 and granulocyte macrophage colony-stimulating factor in mice (Iuvone et al. 2003). Another study reports that the aqueous extract enhances nitric oxide synthetase activity of the macrophages, activates and mobilizes macrophages for rendering increased phagocytic activity and potentiates activity of lysosomal enzymes (Rasool and Varalakshmi 2006). In a docking study, withanolides (withanolide $\mathrm{G}$, withanolide I and withanolide M) have shown binding affinity for PLpro, 3CLpro and spike protein, respectively (Khanal et al. 2021). Withaferin may bind to spike protein causing interference in viral S-protein binding to host receptor and a lack of effect on ACE2 expression in the lungs (Straughn and Kakar 2020). Withanone, 


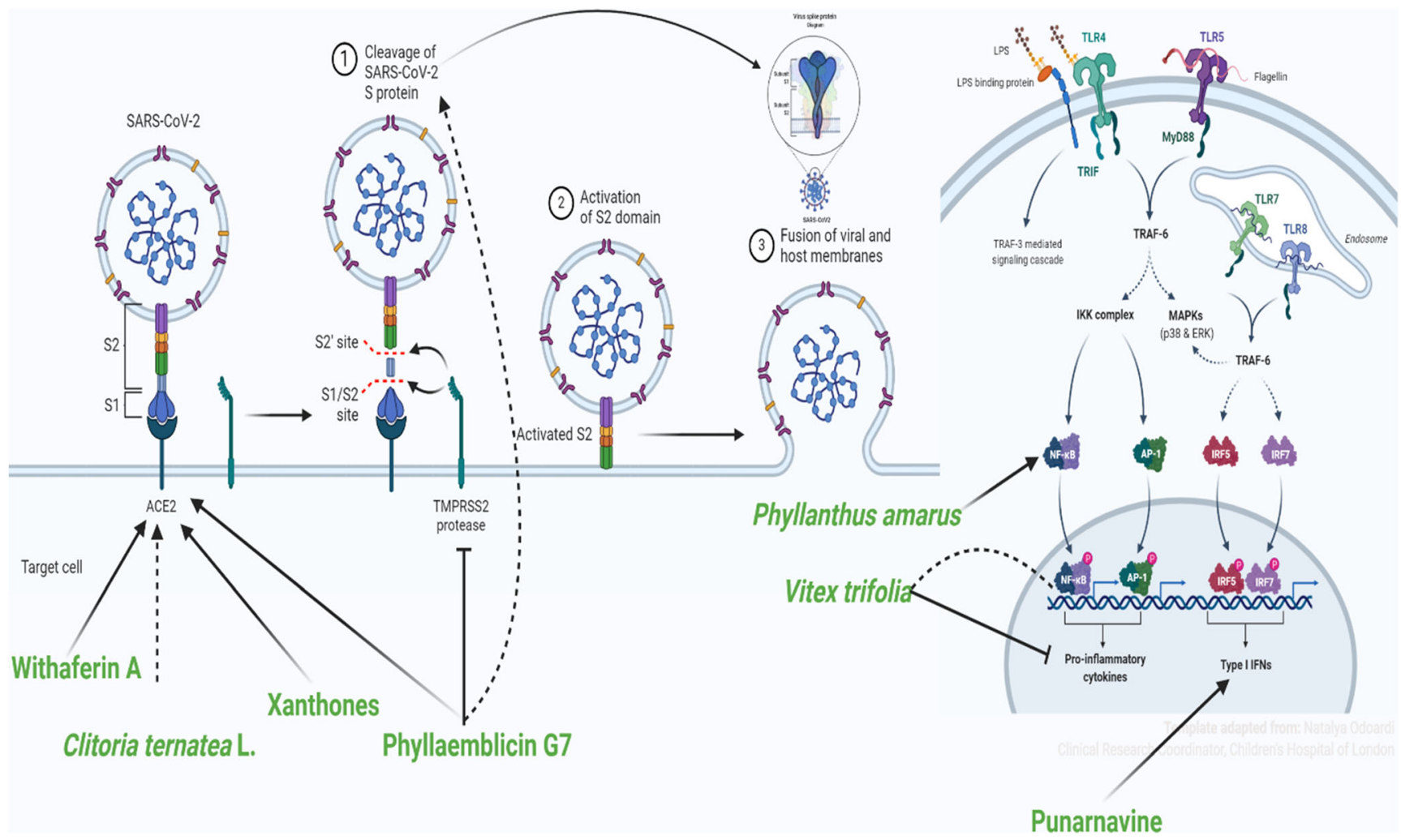

Fig. 2 Possible mechanism of actions of various plants/phytoconstituents against CoV Withaferin A, Clitoria ternatea, xanthones and phyllaemblicin G7 act through ACE2; phyllaemblicin G7 inhibited TMPRSS2 and Vitex trifolia inhibited proinflammatory cytokines (created with BioRender.com)

another compound found in W. somnifera, docked very well in the binding interface of AEC2-RBD complex; this suggests withanone may interrupt interactions between the RBD and ACE2 by destabilizing the complex of ACE2 and RBD of spike protein and thus interfere with virus entry and its subsequent infectivity (Balkrishna et al. 2020b). W. somnifera aqueous extract along with fatty acids inhibits pro-inflammatory cytokines (IL-6 and TNF- $\alpha$ ) along with reduced NF-KB expression (Balkrishna et al. 2020a). There is also an excessive generation of pro-inflammatory cytokines known as cytokine storm in SARS-CoV-2 (Guan et al. 2020; Tang et al. 2020). W. somnifera may reduce pro-inflammatory cytokines and mitigate cytokine storm, modulate inflammatory receptor protein and inhibit the NF- $\mathrm{KB}$ expression in COVID-19 patients (Saggam et al. 2021). W. somnifera is found to be safe in clinical studies (Raut et al. 2012; Langade et al. 2019).

Fig. 3 Utility of Ayurveda

Rasayana herbs as primary therapy towards viral infections

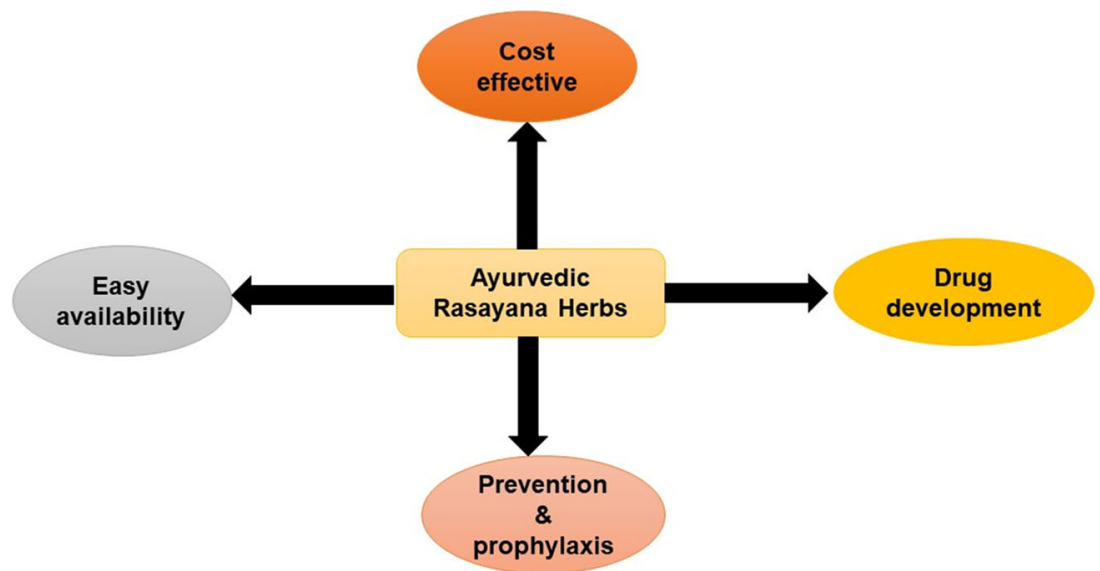




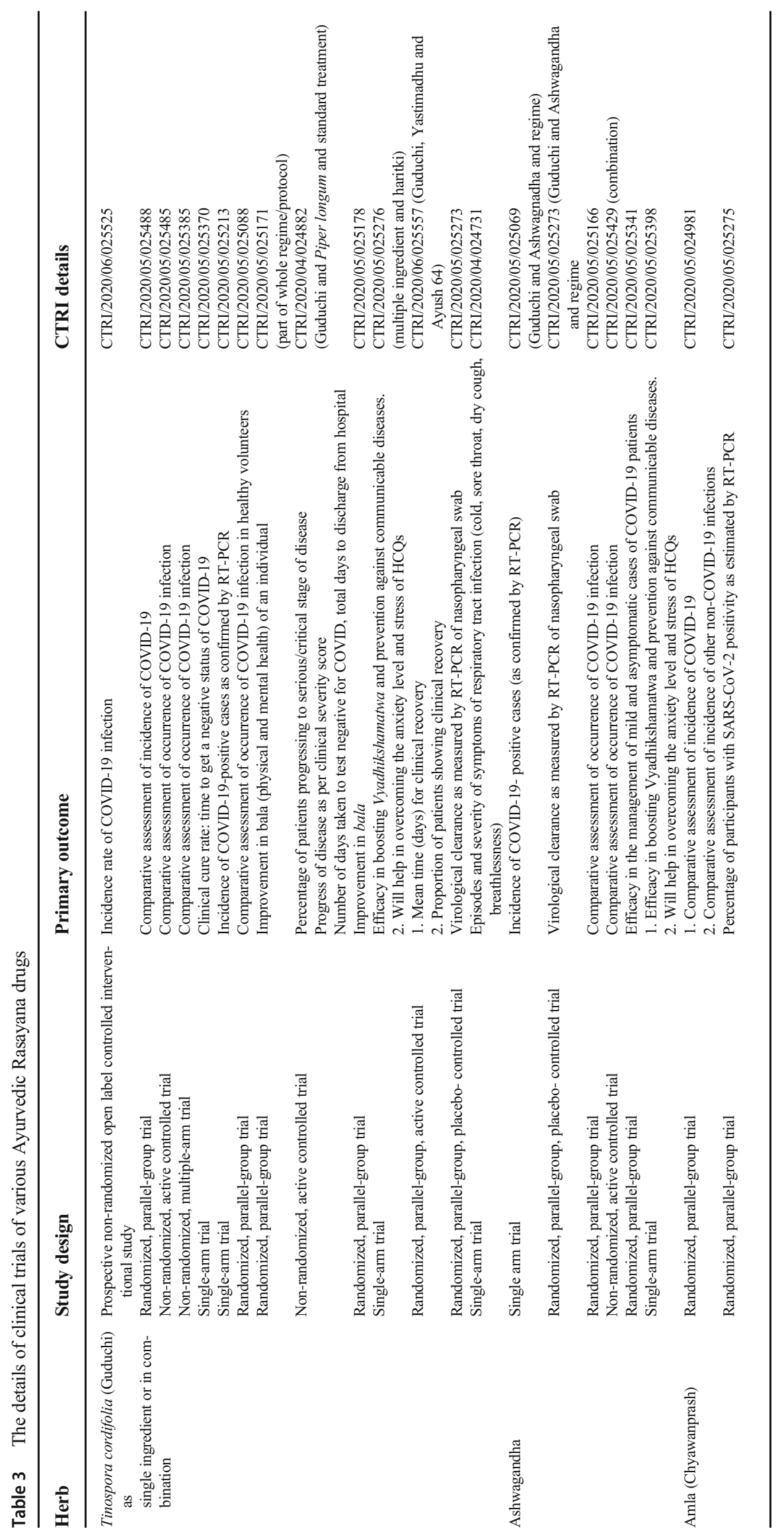


Fig. 4 Prominent phytoconstituents of various Rasayana herbs possible effective against COVID-19<smiles>OC1CCN2Cc3ccccc3N=C12</smiles>

Vasicine

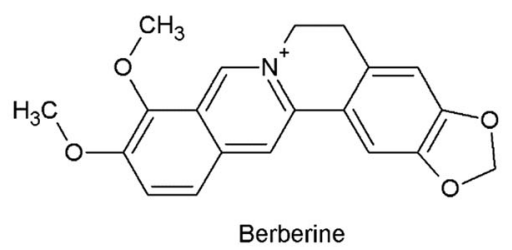

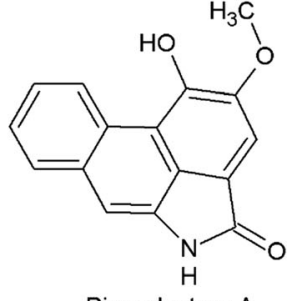

Piperolactam A<smiles></smiles><smiles>COC(=O)C1=C2C(OC3OC(CO)C(O)C(O)C3O)CC3(O)C(=O)OC(c4ccoc4)CC3(C)C2CCC1</smiles>

Cordioside<smiles>CC1(C)C=Cc2c(O)ccc(C3COc4cc(O)cc(O)c4C3=O)c2O1</smiles>

Glyasperin F

Glycyrrhizic acid

Further, the details of the possible herbs that can investigate and be utilized against COVID-19 are given in Table 2, and a mechanistic approach showing possible mechanism of action of various plants/phytoconstituents is presented in Fig. 2.

\section{Discussion}

Plant-based traditional medicines have been used for centuries (Petrovska 2012). Herbs with potential effect on virus receptors or their target sites or interfering viral replication process can be used as antiviral apart from being potent immune enhancers or modulators (Mukhtar et al. 2008; Khanna et al. 2021). There is ample evidences of traditional medicines being used to treat the viral infection through enhancing the immunity of the body (Patwardhan and Gautam 2005). Plants as a whole and through variety of metabolites are useful for therapeutic purposes, like cessation of viral proliferations by regulating its adsorption, binding to host cell receptors, inhibition of fusion of virus into the host cell membrane and by modulating intracellular signals (Gautam et al. 2004; Fuzimoto and Isidoro 2020).
Rasayana herbs help in improving immunogenicity and work as potential immunomodulators (Doshi et al. 2013). These herbs have shown their potential to modulate immune targets such as dendritic, Th1/Th2 and NK cells (Patwardhan and Gautam 2005). In addition, they also have preferential effects on Th1/ Th2 immunity, which is one of emerging targets for adjuvant discovery (Saggam et al. 2021). Experimental studies have established oral adjuvant activity of selected Rasayana botanicals with diphtheria, pertussis (whooping cough) and tetanus (DPT) vaccine (Gautam et al. 2004). This implies that Rasayana herbs can be used in conjunction with vaccines and have the potential to be used as an adjuvant. Furthermore, vaccines provide specific immunity by injecting antigens/attenuated pathogens etc., which require boosters at regular intervals. There are fewer recombinant viral vaccines in use, more similar in approach to those recently licensed for SARS-CoV-2. The majority of viral vaccines do not escape strains due to evolvement of antigenic drift or reassortment as happened in influenza virus (Williams and Burgers 2021). Similarly, the new variants of SARS-CoV-2 is emerging very fast, making control of SAR-CoV-2 even more difficult (van Oosterhout et al. 2021). However, the mutation rate is slower than other RNA viruses (Callaway 2020). 
Majority of the plants discussed in this article are commonly found herbs that are less expensive and may be effectively used for enhancing non-specific immunity among individuals. This may also aid in the relief of associated symptoms and the prevention of co-infections. The host defence mechanism may be strengthened in this scenario. Rasayana herbs help in developing non-specific immunity. NK cells are involved in non-specific innate resistance, but they also play roles in adaptive immunity by promoting the development of antigenspecific Th1 cells by producing IFN- and IL-2. A better NK effector cell response [via IFN production and cytotoxic granule exocytosis] directly contributes to virus neutralization (Cook et al. 2014; Boucher and Boucher 2020). In other words, a better NK effector cell response directly contributes to virus neutralization (Horowitz et al. 2010) and the efficiency with which specific antigens are developed during infection. NK cells specialize as memory NK cells during an infection, mediating protection against a second infection by the same pathogen. Children have had the highest resistance to COVID-19 since the beginning of the pandemic, but this resistance gradually decreases with age (Ludvigsson 2020). Here the Rasayana herbs may contribute and play a pivotal role. These Ayurveda Rasayana with a multipronged approach of salutogenesis (by immune-enhancing/modulating activities) and direct antiviral effect may certainly play a pivotal role in future approaches towards such viral infections and epidemics. Further, taking leads from this for future studies on COVID-19 and similar pandemics and/or viral diseases will be beneficial in number of ways as elucidated in Fig. 3 .

The herbs reviewed in this paper can be utilized and studied for their multipronged action against COVID-19. A unique strategy can be envisaged based on immunity in Ayurveda in two-fold prongs, viz. boosting immunity or improve resistance to fight against SARS-CoV-2 and to look the antiviral activities of these Rasayana herbs. For instance, A. vasica can help in symptomatic management of respiratory symptoms along with $\mathrm{T}$ cell-mediated activity against viral invasion in the respiratory mucosa. A. vasica in regular practice is used for the management of non-specific viral respiratory diseases in Ayurveda (Gupta and Prajapati 2010). Herbs with immune potentiating properties like A. racemosus, P. longum, $S$. suaveolens and $T$. chebula can be studied for their effectiveness and efficacy in prophylactic care against COVID-19.

To address the complications especially inflammatory reaction in lung cells, E. ribes can be a promising candidate with its lung-protective and anti-inflammatory activity as studied in acute respiratory syndrome and a good antiviral activity against a number of viral infections including flu. $B$. diffusa can help in sustained immune response, controlling pro-inflammatory cytokine release, thus can help in preventing cytokine storm-like complications. The broad-spectrum antiviral agents are those which act by inhibition of viral or host factors thereby blocking its replication. They also reduce the viral burden to a level so that the host immune responses can deal with it or facilitate apoptosis of infected cells (Andersen et al. 2020). Certain herbs may provide promising leads through direct antiviral activity against SARS-CoV-2 like G. glabra.

Ayurveda Rasayana herbs can be used as an add-on to other antiviral agents or multi-herb formulations to get a synergistic effect against COVID-19 and other viral infections. Such combinations can certainly play a pivotal role as the first line of management against a variety of viral infections (Andersen et al. 2020). Various clinical studies are under progress to study G. glabra and W. somnifera whole extract in the management of COVID-19 as add-on to other clinically used medicines. Other plant studies here might also offer promising leads based on scientific studies and thus might serve as suitable candidates which can be further taken up of study against COVID-19.

There are numerous ongoing clinical trials on traditional medicines in India. The data collected from the Clinical Trials Registry-India (CTRI) reports 122 clinical trials registered on COVID-19 in which sixty-seven pertains to AYUSH systems which include traditional system like Ayurveda, Unani, Siddha, Yoga and Naturopathy and Homoeopathy. Out of sixty-seven, majority of traditional medicine trials comprised of Ayurveda. The maximum is related to Tinospora cordifolia, Withania somnifera and Glycyrrhiza glabra either in combination or as a single ingredient also ranging from asymptomatic to moderate to severe COVID-19 patients as shown in Table 3.

However, the maximum number of preventive studies is being up in high-risk population rather than in healthy individuals. Two studies were also reported on Chyawanprash wherein the Emblica officinalis was the main ingredient. The maximum trails are government sponsored and focusing on the preventive aspect of these medicinal plants (Londhe et al. 2020). It is highly recommended to explore the possibility of drug development from at least some of the prominent phytochemicals as mentioned in Fig. 4.

\section{Conclusion}

Rasayana herbs exhibit non-specific immunity, which may not be attributable to specificity; however, individual studies of this Rasayana have shown activity against SARS-CoV-2 in various experimental settings. However, this may not be comparable to a vaccine as both have a different mode of action; hence, sensitivity does not imply to Rasayana herbs therapy. The cost of herbs mentioned in the study is significantly less compared to the vaccine; however, these are in no ways a substitute to the vaccine, and our arguments are these can be used concomitantly with vaccine. Use of vaccines should be indeed the primary option for the protection from this pandemic; however, it is also very important to have a robust mechanism for adverse reaction reporting and pharmacovigilance of the vaccine use. 
Still considering common factors of cost-benefit analysis like cost of drugs, setup for the administration of a drug, healthcare provider fees, logistics and other related cost, the cost of a Rasayana which does not need any special setup for administration, has no special logistic care and is locally available at many part globe will be substantially lower than other counterparts. The Rasayana herbs can help in resisting any pathogenic invasion by virtue of its immune potentiating and immune modulating property and via imparting non-specific immunity. As we have discussed in this paper, few of these herbs have been studied for providing specific immunity through direct antiviral properties against certain viral infections. Though, a clear mechanism of the same is still unexplored owing to complex phytochemical constituents which are acting on different targets of SARS-CoV2 apart from salutogenic approach. Hence, there is a potential need to conduct comprehensive preclinical and clinical studies to explore the therapeutic effects and mechanism of actions of these Rasayana drugs.

Taking leads from Ayurveda and traditional medicine may be used for further studies which will help in reducing time in drug discovery in this pandemic time for COVID-19. A consortium of Ayurveda and other traditional medicine, modern medicine and basic biology can provide a platform for real discovery engine from traditional wisdom to newer, safer, cheaper and effective therapies. Such approaches are a need of the hour, and medicinal herbs must be utilized to the greatest extent with incorporation of fundamentals of the traditional medicine through Ayurveda biology approach.

Author contribution All authors contributed equally in the study. RS and SG conceptualized the study and prepared the primary draft, DT planned the framework of manuscript and done the final editing, PB and LA review and revised the manuscript. Discussion part was discussed among all authors.

Data availability All data generated or analysed during this study are included in this published article.

\section{Declarations}

Ethics approval Not applicable

Consent to participate Not applicable

Consent for publication Not applicable

Competing interests The authors declare no competing interests.

\section{References}

(FEEDAP) EP on A and P or S used in AF (2015) Scientific opinion on the safety and efficacy of glycyrrhizic acid ammoniated (chemical group 30, miscellaneous substances) when used as a flavouring for all animal species. EFSA J 13:3971
Afolayan FID, Erinwusi B, Oyeyemi OT (2018) Immunomodulatory activity of curcumin-entrapped poly d,1-lactic-co-glycolic acid nanoparticles in mice. Integr Med Res 7:168-175. https://doi.org/10. 1016/j.imr.2018.02.004

Afshari AR, Sadeghnia HR, Mollazadeh H (2016) A review on potential mechanisms of Terminalia chebula in Alzheimer's disease. Adv Pharmacol Sci 2016:8964849-8964814. https://doi.org/10.1155/ 2016/8964849

Aggarwal LM, Chacko MK, Kuruvilla TB (2016) Systematic and comprehensive investigation of the toxicity of curcuminoid-essential oil complex: a bioavailable turmeric formulation. Mol Med Rep 13: 592-604. https://doi.org/10.3892/mmr.2015.4579

Ahmad S, Zahiruddin S, Parveen B et al (2021) Indian medicinal plants and formulations and their potential against COVID-19-preclinical and clinical research. Front. Pharmacol. 11:2470

Ajala TO, Femi-Oyewo MN, Odeku OA et al (2016) The physicochemical, safety and antimicrobial properties of Phyllanthus amarus herbal cream and ointment. J Pharm Investig 46:169-178. https://doi. org/10.1007/s40005-015-0226-8

Alajmi MF, Mothana RA, Al-Rehaily AJ, Khaled JM (2018) Antimycobacterial activity and safety profile assessment of Alpinia galanga and Tinospora cordifolia. Evidence-Based Complement Altern Med 2018:2934583-2934512. https://doi.org/10.1155/ 2018/2934583

Alam G, Wahyuono S, Ganjar IG, Hakim L, Timmerman H, Verpoorte R (2002) Tracheospasmolytic activity of viteosin-A and vitexicarpin isolated from vitex trifolia. Planta Med. 68:1047-1049

Albensi BC (2019) What is nuclear factor kappa B (NF-kB) doing in and to the mitochondrion? Front. Cell Dev. Biol. 7:154

Ali M, Sansthan MC, Parvej S, Kumar R (2015) Immunomodulatory effect of Withania somnifera (ashwagandha) on cyclophosphamide induced toxicity in rats. Am J PharmTech Res 5:638-645

Alok S, Jain SK, Verma A, Kumar M, Mahor A, Sabharwal M (2013) Plant profile, phytochemistry and pharmacology of Asparagus racemosus (Shatavari): a review. Asian Pacific J Trop Dis 3:242251. https://doi.org/10.1016/S2222-1808(13)60049-3

Andersen PI, Ianevski A, Lysvand H, Vitkauskiene A, Oksenych V, Bjørås M, Telling K, Lutsar I, Dumpis U, Irie Y, Tenson T, Kantele A, Kainov DE (2020) Discovery and development of safe-in-man broad-spectrum antiviral agents. Int J Infect Dis IJID Off Publ Int Soc Infect Dis 93:268-276. https://doi.org/10.1016/j. ijid.2020.02.018

Antony S, Kuttan R, Kuttan G (1999) Immunomodulatory activity of curcumin. Immunol Invest 28:291-303. https://doi.org/10.3109/ 08820139909062263

Aranha I, Clement F, Venkatesh YP (2012) Immunostimulatory properties of the major protein from the stem of the Ayurvedic medicinal herb, guduchi (Tinospora cordifolia). J Ethnopharmacol 139:366372. https://doi.org/10.1016/j.jep.2011.11.013

Arora R, Chawla R, Marwah R, Arora P, Sharma RK, Kaushik V, Goel R, Kaur A, Silambarasan M, Tripathi RP, Bhardwaj JR (2011) Potential of complementary and alternative medicine in preventive management of novel H1N1 flu (swine flu) pandemic: thwarting potential disasters in the bud. Evid Based Complement Alternat Med 2011:586506-586516. https://doi.org/10.1155/2011/586506

Bachmetov L, Gal-Tanamy M, Shapira A, Vorobeychik M, GitermanGalam T, Sathiyamoorthy P, Golan-Goldhirsh A, Benhar I, TurKaspa R, Zemel R (2012) Suppression of hepatitis C virus by the flavonoid quercetin is mediated by inhibition of NS3 protease activity. J Viral Hepat 19:e81-e88. https://doi.org/10.1111/j.1365-2893. 2011.01507.x

Badam L (1997) In vitro antiviral activity of indigenous glycyrrhizin, licorice and glycyrrhizic acid (Sigma) on Japanese encephalitis virus. J Commun Dis 29:91-99

Bae G-S, Kim M-S, Jeong J, Lee HY, Park KC, Koo BS, Kim BJ, Kim TH, Lee SH, Hwang SY, Shin YK, Song HJ, Park SJ (2011) 
Piperine ameliorates the severity of cerulein-induced acute pancreatitis by inhibiting the activation of mitogen activated protein kinases. Biochem Biophys Res Commun 410:382-388. https://doi. org/10.1016/j.bbrc.2011.05.136

Bafna K, Krug RM, Montelione GT (2020) Structural similarity of SARS-CoV2 M(pro) and HCV NS3/4A proteases suggests new approaches for identifying existing drugs useful as COVID-19 therapeutics. ChemRxiv Prepr Serv Chem https://doi.org/10.26434/ chemrxiv.12153615.v1

Bag A, Bag A (2020) Treatment of COVID-19 patients: Justicia adhatoda leaves extract is a strong remedy for COVID-19 - case report analysis and docking based study. Prepr https//doi org/1026434/ chemrxiv 12038604:v1

Bag A, Bhattacharyya SK, Chattopadhyay RR (2013) The development of Terminalia chebula Retz. (Combretaceae) in clinical research. Asian Pac J Trop Biomed 3:244-252. https://doi.org/10.1016/ S2221-1691(13)60059-3

Balasubramanian G, Sarathi M, Kumar SR, Hameed ASS (2007) Screening the antiviral activity of Indian medicinal plants against white spot syndrome virus in shrimp. Aquaculture 263:15-19. https://doi.org/10.1016/j.aquaculture.2006.09.037

Balasubramanian T, Chatterjee TK, Senthilkumar GP, Mani T (2012) Effect of potent ethyl acetate fraction of Stereospermum suaveolens extract in streptozotocin-induced diabetic rats. Sci World J 2012: 413196-413198. https://doi.org/10.1100/2012/413196

Balkrishna A, Nain P, Chauhan A, Sharma N, Gupta A, Ranjan R, Varshney A (2020a) Super critical fluid extracted fatty acids from Withania somnifera seeds repair psoriasis-like skin lesions and attenuate pro-inflammatory cytokines (TNF- $\alpha$ and IL-6) release. Biomolecules 10:185

Balkrishna A, POKHREL S, Singh J, Varshney A (2020b) Withanone from Withania somnifera may inhibit novel coronavirus (COVID19) entry by disrupting interactions between viral S-protein receptor binding domain and host ACE2 receptor

Banerjee N, Saha B, Mukhopadhyay S (2018) Intracellular ROS generated in chikungunya patients with persisting polyarthralgia can be reduced by Tinospora cordifolia leaf extract. Virusdisease 29:375379. https://doi.org/10.1007/s13337-018-0465-1

Bani S, Gautam M, Sheikh FA, Khan B, Satti NK, Suri KA, Qazi GN, Patwardhan B (2006) Selective Th1 up-regulating activity of Withania somnifera aqueous extract in an experimental system using flow cytometry. J Ethnopharmacol 107:107-115. https://doi. org/10.1016/j.jep.2006.02.016

Belapurkar P, Goyal P, Tiwari-Barua P (2014) Immunomodulatory effects of triphala and its individual constituents: a review. Indian J Pharm Sci 76:467-475

Bhakuni DS, Dhar ML, Dhar MM, Dhawan BN, Gupta B, Srimal RC (1971) Screening of Indian plants for biological activity. 3. Indian J Exp Biol 9:91-102

Bhalerao S, Vyawahare N, Saldhana T et al (2013) Evaluation of effect of methanolic extract of Stereospermum suaveolens in the asthmatic animal. JPR BioMedRx An Int J 1:599-607

Bhandari U, Kanojia R, Pillai KK (2002) Effect of ethanolic extract of Embelia ribes on dyslipidemia in diabetic rats. Int J Exp Diabetes Res 3:159-162. https://doi.org/10.1080/15604280214278

Bopana N, Saxena S (2007) Asparagus racemosusethnopharmacological evaluation and conservation needs. J Ethnopharmacol 110:1-15. https://doi.org/10.1016/j.jep.2007.01. 001

Bordbar N, Karimi MH, Amirghofran Z (2012) The effect of glycyrrhizin on maturation and $\mathrm{T}$ cell stimulating activity of dendritic cells. Cell Immunol 280:44-49. https://doi.org/10.1016/j.cellimm.2012.11. 013

Bose M, Kamra M, Mullick R, Bhattacharya S, Das S, Karande AA (2017) A plant-derived dehydrorotenoid: a new inhibitor of hepatitis
C virus entry. FEBS Lett 591:1305-1317. https://doi.org/10.1002/ 1873-3468.12629

Boucher P, Boucher R (2020) Improving non-specific immunity to coronavirus disease (COVID-19) by the novelty, diversity, and quantity of antigen. Front public Heal 8:393. https://doi.org/10.3389/fpubh. 2020.00393

Bunte K, Beikler T (2019) Th17 cells and the IL-23/IL-17 axis in the pathogenesis of periodontitis and immune-mediated inflammatory diseases. Int J Mol Sci 20. https://doi.org/10.3390/ijms20143394

Callaway E (2020) The coronavirus is mutating - does it matter? Nature 585:174-177

Caruso F, Rossi M, Pedersen JZ, Incerpi S (2020) Computational studies reveal mechanism by which quinone derivatives can inhibit SARSCoV-2. Study of embelin and two therapeutic compounds of interest, methyl prednisolone and dexamethasone. J Infect Public Health 13:1868-1877. https://doi.org/10.1016/j.jiph.2020.09.015

Castillo AL, Osi MO, Ramos JDA, de Francia JL, Dujunco MU, Quilala PF (2013) Efficacy and safety of Tinospora cordifolia lotion in Sarcoptes scabiei var hominis-infected pediatric patients: a single blind, randomized controlled trial. J Pharmacol Pharmacother 4: 39-46. https://doi.org/10.4103/0976-500X.107668

Cecere TE, Todd SM, Leroith T (2012) Regulatory T cells in arterivirus and coronavirus infections: do they protect against disease or enhance it? Viruses 4:833-846. https://doi.org/10.3390/v4050833

Chanda D, Shanker K, Pal A, Luqman S, Bawankule DU, Mani D, Darokar MP (2009) Safety evaluation of Trikatu, a generic Ayurvedic medicine in Charles Foster rats. J Toxicol Sci 34:99108. https://doi.org/10.2131/jts.34.99

Chandrasekaran CV, Mathuram LN, Daivasigamani P, Bhatnagar U (2009) Tinospora cordifolia, a safety evaluation. Toxicol In Vitro 23:1220-1226. https://doi.org/10.1016/j.tiv.2009.07.030

Chatterjee A, Chattopadhyay S, Bandyopadhyay SK (2011) Biphasic effect of Phyllanthus emblica L. extract on NSAID-induced ulcer: an antioxidative trail weaved with immunomodulatory effect. Evid Based Complement Alternat Med 2011:146808. https://doi.org/10. 1155/2011/146808

Chavan R, Gohil D, Shah V, et al (2013) Antiviral activity of Indian medicinal plant Justicia adhatoda against herpes simplex virus: an in-vitro study. Int J Pharm Bio Sci 4:

Chen N, Zhou M, Dong X, Qu J, Gong F, Han Y, Qiu Y, Wang J, Liu Y, Wei Y, Xia J', Yu T, Zhang X, Zhang L (2020) Epidemiological and clinical characteristics of 99 cases of 2019 novel coronavirus pneumonia in Wuhan, China: a descriptive study. Lancet (London, England) 395:507-513. https://doi.org/10.1016/S0140-6736(20) 30211-7

Chikhale RV, Sinha SK, Patil RB, Prasad SK, Shakya A, Gurav N, Prasad R, Dhaswadikar SR, Wanjari M, Gurav SS (2020) In-silico investigation of phytochemicals from Asparagus racemosus as plausible antiviral agent in COVID-19. J Biomol Struct Dyn 39:1-15. https://doi.org/10.1080/07391102.2020.1784289

Chowdhury P (2020) In silico investigation of phytoconstituents from Indian medicinal herb "Tinospora cordifolia (giloy)" against SARS-CoV-2 (COVID-19) by molecular dynamics approach. J Biomol Struct Dyn:1-18. https://doi.org/10.1080/07391102.2020. 1803968

Chrzanowski J, Chrzanowska A, Graboń W (2021) Glycyrrhizin: an old weapon against a novel coronavirus. Phyther Res 35:629-636. https://doi.org/10.1002/ptr.6852

Chulet R, Pradhan P (2009) A review on rasayana. Pharmacogn Rev 3: 229

Cinatl J, Morgenstern B, Bauer G, Chandra P, Rabenau H, Doerr HW (2003) Glycyrrhizin, an active component of liquorice roots, and replication of SARS-associated coronavirus. Lancet (London, England) 361:2045-2046. https://doi.org/10.1016/s0140-6736(03) 13615 -x 
Cook KD, Waggoner SN, Whitmire JK (2014) NK cells and their ability to modulate $\mathrm{T}$ cells during virus infections. Crit Rev Immunol 34: 359-388. https://doi.org/10.1615/critrevimmunol.2014010604

Coon JT, Ernst E (2004) Andrographis paniculata in the treatment of upper respiratory tract infections: a systematic review of safety and efficacy. Planta Med 70:293-298. https://doi.org/10.1055/s-2004818938

Dar NJ, Hamid A, Ahmad M (2015) Pharmacologic overview of Withania somnifera, the Indian ginseng. Cell Mol Life Sci 72: 4445-4460. https://doi.org/10.1007/s00018-015-2012-1

de Candia P, Prattichizzo F, Garavelli S, Matarese G (2021) T cells: warriors of SARS-CoV-2 infection. Trends Immunol 42:18-30. https://doi.org/10.1016/j.it.2020.11.002

Dhar ML, Dhar MM, Dhawan BN, Mehrotra BN, Ray C (1968) Screening of Indian plants for biological activity: I. Indian J Exp Biol 6:232-247

Dhawan BN (2012) Anti-viral activity of Indian plants. Proc Natl Acad Sci India Sect B 82:209-224. https://doi.org/10.1007/s40011-0110016-7

Dhuley JN (1999) Antitussive effect of Adhatoda vasica extract on mechanical or chemical stimulation-induced coughing in animals. J Ethnopharmacol 67:361-365. https://doi.org/10.1016/S03788741(99)00074-4

Diallo D, Hveem B, Mahmoud MA, Berge G, Paulsen BS, Maiga A (1999) An ethnobotanical survey of herbal drugs of Gourma District, Mali. Pharm Biol 37:80-91. https://doi.org/10.1076/phbi. 37.1.80.6313

Doshi GM, Une HD, Shanbhag PP (2013) Rasayans and non-rasayans herbs: future immunodrug - targets. Pharmacogn Rev 7:92-96. https://doi.org/10.4103/0973-7847.120506

Durg S, Naveen BK, Vandal R et al (2017) Antipsychotic activity of embelin isolated from Embelia ribes: a preliminary study. Biomed Pharmacother 90:328-331. https://doi.org/10.1016/j.biopha.2017. 03.085

Dwivedi S, Ghatuary SK, Prasad S et al (2019) Phytochemical screening and in vivo anti-inflammatory activity of hydroalcoholic extract of Embelia ribes Burm. F. J Drug Deliv Ther 9:386-389

El-Saber Batiha G, Magdy Beshbishy A, El-Mleeh A et al (2020) Traditional uses, bioactive chemical constituents, and pharmacological and toxicological activities of Glycyrrhiza glabra L. (Fabaceae). Biomolecules 10:352. https://doi.org/10.3390/biom10030352

Enquist LW (2009) Virology in the 21st century. J Virol 83:5296-5308. https://doi.org/10.1128/JVI.00151-09

Fiore C, Eisenhut M, Krausse R, Ragazzi E, Pellati D, Armanini D, Bielenberg J (2008) Antiviral effects of Glycyrrhiza species. Phytother Res 22:141-148. https://doi.org/10.1002/ptr.2295

Fuzimoto AD, Isidoro C (2020) The antiviral and the coronavirus-host protein pathways inhibiting properties of herbs and natural compounds-additional weapons in the fight against the COVID-19 pandemic? J Tradit Complement Med

Ganjhu RK, Mudgal PP, Maity H, Dowarha D, Devadiga S, Nag S, Arunkumar G (2015) Herbal plants and plant preparations as remedial approach for viral diseases. Virusdisease 26:225-236. https:// doi.org/10.1007/s13337-015-0276-6

Gautam M, Diwanay SS, Gairola S, Shinde YS, Jadhav SS, Patwardhan BK (2004) Immune response modulation to DPT vaccine by aqueous extract of Withania somnifera in experimental system. Int Immunopharmacol 4:841-849. https://doi.org/10.1016/j.intimp. 2004.03.005

Gautam M, Saha S, Bani S, Kaul A, Mishra S, Patil D, Satti NK, Suri KA, Gairola S, Suresh K, Jadhav S, Qazi GN, Patwardhan B (2009) Immunomodulatory activity of Asparagus racemosus on systemic Th1/Th2 immunity: implications for immunoadjuvant potential. J Ethnopharmacol 121:241-247. https://doi.org/10.1016/j.jep.2008. 10.028
George A, Udani JK, Yusof A (2019a) Effects of Phyllanthus amarus PHYLLPRO(TM) leaves on hangover symptoms: a randomized, double-blind, placebo-controlled crossover study. Pharm Biol 57: 145-153. https://doi.org/10.1080/13880209.2019.1585460

George A, Udani JK, Yusof A (2019b) Effects of Phyllanthus amarus PHYLLPROTM leaves on hangover symptoms: a randomized, double-blind, placebo-controlled crossover study. Pharm Biol 57:145153. https://doi.org/10.1080/13880209.2019.1585460

Gheware A, Dholakia D, Kannan S, Panda L, Rani R, Pattnaik BR, Jain V, Parekh Y, Enayathullah MG, Bokara KK, Subramanian V, Mukerji M, Agrawal A, Prasher B (2021a) Adhatoda Vasica attenuates inflammatory and hypoxic responses in preclinical mouse models: potential for repurposing in COVID-19-like conditions. Respir Res 22:99. https://doi.org/10.1186/s12931-021-01698-9

Gheware A, Panda L, Khanna K, Bhatraju NK, Jain V, Sagar S, Kumar M, Singh VP, Kannan S, Subramanian V, Mukerji M, Agrawal A, Prasher B (2021b) Adhatoda vasica rescues the hypoxia-dependent severe asthma symptoms and mitochondrial dysfunction. Am J Physiol Lung Cell Mol Physiol 320:L757-L769. https://doi.org/ 10.1152/ajplung.00511.2020

Ghosh T, Chattopadhyay K, Marschall M, Karmakar P, Mandal P, Ray B (2009) Focus on antivirally active sulfated polysaccharides: From structure-activity analysis to clinical evaluation. Glycobiology 19:215

Ghosh A, Nundy S, Mallick TK (2020) How India is dealing with COVID-19 pandemic. Sensors Int 1:100021. https://doi.org/10. 1016/j.sintl.2020.100021

Ghosh R, Chakraborty A, Biswas A, Chowdhuri S (2021) Identification of alkaloids from Justicia adhatoda as potent SARS CoV-2 main protease inhibitors: an in silico perspective. J Mol Struct 1229: 129489. https://doi.org/10.1016/j.molstruc.2020.129489

Girija PLT, Sivan N (2020) Ayurvedic treatment of COVID-19/SARSCoV-2: a case report. J Ayurveda Integr Med S0975-9476(20): 30042-30045. https://doi.org/10.1016/j.jaim.2020.06.001

Gomaa AA, Abdel-Wadood YA (2021) The potential of glycyrrhizin and licorice extract in combating COVID-19 and associated conditions. Phytomedicine Plus 1:100043. https://doi.org/10.1016/j.phyplu. 2021.100043

Gonzalez O, Fontanes V, Raychaudhuri S, Loo R, Loo J, Arumugaswami V, Sun R, Dasgupta A, French SW (2009) The heat shock protein inhibitor quercetin attenuates hepatitis $\mathrm{C}$ virus production. Hepatology 50:1756-1764. https://doi.org/10.1002/hep.23232

Goyal RK, Singh J, Lal H (2003) Asparagus racemosus-an update. Indian J Med Sci 57:408-414

Guan W, Ni Z, Hu Y, Liang WH, Ou CQ, He JX, Liu L, Shan H, Lei CL, Hui DSC, du B, Li LJ, Zeng G, Yuen KY, Chen RC, Tang CL, Wang T, Chen PY, Xiang J et al (2020) Clinical characteristics of coronavirus disease 2019 in China. N Engl J Med 382:1708-1720. https://doi.org/10.1056/NEJMoa2002032

Gupta A, Prajapati PK (2010) A clinical review of different formulations of Vasa (Adhatoda vasica) on Tamaka Shwasa (asthma). Ayu 31: 520-524. https://doi.org/10.4103/0974-8520.82032

Gupta S, Sanyal SN, Kanwar U (1989) Antispermatogenic effect of embelin, a plant benzoquinone, on male albino rats in vivo and in vitro. Contraception 39:307-320

Gurav NS, Gurav SS, Sakharwade SN (2020) Studies on Ashwagandha Ghrita with reference to murcchana process and storage conditions. J Ayurveda Integr Med 11:243-249. https://doi.org/10.1016/j.jaim. 2019.10.004

Harikrishnan H, Jantan I, Haque MA, Kumolosasi E (2018) Antiinflammatory effects of Phyllanthus amarus Schum. \& Thonn. through inhibition of NF- $\mathrm{KB}, \mathrm{MAPK}$, and PI3K-Akt signaling pathways in LPS-induced human macrophages. BMC Complement Altern Med 18:224. https://doi.org/10.1186/s12906-018-2289-3

Harikrishnan H, Jantan I, Alagan A, Haque MA (2020) Modulation of cell signaling pathways by Phyllanthus amarus and its major 
constituents: potential role in the prevention and treatment of inflammation and cancer. Inflammopharmacology 28:1-18. https://doi. org/10.1007/s10787-019-00671-9

Harish GU, Danapur V, Jain R, Patell VM (2012) Endangered medicinal plant Embelia ribes Burm.f.- a review. Pharmacogn J 4:6-19. https:// doi.org/10.5530/pj.2012.27.2

Hegde NR, Rao PP, Bayry J, Kaveri SV (2009) Immunotherapy of viral infections. Immunotherapy 1:691-711. https://doi.org/10.2217/imt. 09.26

Hiremath S, Kumar HDV, Nandan M, Mantesh M, Shankarappa KS, Venkataravanappa V, Basha CRJ, Reddy CNL (2021) In silico docking analysis revealed the potential of phytochemicals present in Phyllanthus amarus and Andrographis paniculata, used in Ayurveda medicine in inhibiting SARS-CoV-2. 3 Biotech 11:44. https://doi.org/10.1007/s13205-020-02578-7

Hoever G, Baltina L, Michaelis M, Kondratenko R, Baltina L, Tolstikov GA, Doerr HW, Cinatl J (2005) Antiviral activity of glycyrrhizic acid derivatives against SARS-coronavirus. J Med Chem 48:12561259. https://doi.org/10.1021/jm0493008

Hoffmann M, Kleine-Weber H, Schroeder S, Krüger N, Herrler T, Erichsen S, Schiergens TS, Herrler G, Wu NH, Nitsche A, Müller MA, Drosten C, Pöhlmann S (2020) SARS-CoV-2 cell entry depends on ACE2 and TMPRSS2 and is blocked by a clinically proven protease inhibitor. Cell 181:271-280.e8. https://doi.org/10.1016/ j.cell.2020.02.052

Horowitz A, Behrens RH, Okell L, Fooks AR, Riley EM (2010) NK cells as effectors of acquired immune responses: effector CD4+ T celldependent activation of NK cells following vaccination. J Immunol 185:2808-2818. https://doi.org/10.4049/jimmunol.1000844

Hossan MS, Fatima A, Rahmatullah M, Khoo TJ, Nissapatorn V, Galochkina AV, Slita AV, Shtro AA, Nikolaeva Y, Zarubaev VV, Wiart C (2018) Antiviral activity of Embelia ribes Burm. f. against influenza virus in vitro. Arch Virol 163:2121-2131. https://doi.org/ 10.1007/s00705-018-3842-6

Huabprasert S, Kasetsinsombat K, Kangsadalampai K et al (2012) The Phyllanthus emblica L. infusion carries immunostimulatory activity in a mouse model. J Med Assoc Thai 95 Suppl 2:S75-S82

Ilangkovan M, Jantan I, Bukhari SNA (2016) Phyllanthin from Phyllanthus amarus inhibits cellular and humoral immune responses in Balb/C mice. Phytomedicine 23:1441-1450. https://doi.org/10. 1016/j.phymed.2016.08.002

Ilona G, Stephanie B, Müller AM et al (2011) Evidence that TMPRSS2 activates the severe acute respiratory syndrome coronavirus spike protein for membrane fusion and reduces viral control by the humoral immune response. J Virol 85:4122-4134. https://doi.org/10. 1128/JVI.02232-10

Ismail EN, Jantan I, Vidyadaran S, Jamal JA, Azmi N (2020) Phyllanthus amarus prevents LPS-mediated BV2 microglial activation via MyD88 and NF-KB signaling pathways. BMC Complement Med Ther 20:202. https://doi.org/10.1186/s12906-020-02961-0

Iuvone T, Esposito G, Capasso F, Izzo AA (2003) Induction of nitric oxide synthase expression by Withania somnifera in macrophages. Life Sci 72:1617-1625. https://doi.org/10.1016/s0024-3205(02) 02472-4

Jadhav P, Kapoor N, Thomas B, Lal H, Kshirsagar N (2012) Antiviral potential of selected Indian medicinal (ayurvedic) plants against herpes simplex virus 1 and 2. N Am J Med Sci 4:641-647. https:// doi.org/10.4103/1947-2714.104316

Jaijoy K, Soonthornchareonnon N, Lertprasertsuke N et al (2010a) Acute and chronic oral toxicity of standardized water extract from the fruit of Phyllanthus emblica Linn. Int J Appl Res Nat Prod 3:48-58

Jaijoy K, Soonthornchareonnon N, Panthong A, Sireeratawong S (2010b) Anti-inflammatory activity and toxicity of the standardised water extract of Phyllanthus emblica L. Planta Med 76:P127

Jakhar R, Kaushik S, Gakhar SK (2020) 3CL hydrolase-based multiepitope peptide vaccine against SARS-CoV-2 using immunoinformatics. J Med Virol 92:2114-2123. https://doi.org/ 10.1002/jmv.25993

Janice Oh H-L, Ken-En Gan S, Bertoletti A, Tan Y-J (2012) Understanding the $\mathrm{T}$ cell immune response in SARS coronavirus infection. Emerg Microbes Infect 1:e23. https://oi.org/10.1038/ emi.2012.26

Jena S, Munusami P, Mm B, Chanda K (2021) Computationally approached inhibition potential of Tinospora cordifolia towards COVID-19 targets. VirusDisease 32:65-77. https://doi.org/10. 1007/s13337-021-00666-7

Jiang Z-Y, Liu W-F, Zhang X-M, Luo J, Ma YB, Chen JJ (2013) AntiHBV active constituents from Piper longum. Bioorg Med Chem Lett 23:2123-2127. https://doi.org/10.1016/j.bmcl.2013.01.118

Johri RK, Dhar SK, Pahwa GS, Sharma SC, Kaul JL, Zutshi U (1990) Toxicity studies with potassium embelate, a new analgesic compound. Indian J Exp Biol 28:213-217

Joseph B, Raj SJ (2011) An overview: pharmacognostic properties of Phyllanthus amarus Linn. Int J Pharmacol 7:40-45

Joshi T, Joshi T, Sharma P et al (2020) In silico screening of natural compounds against COVID-19 by targeting Mpro and ACE2 using molecular docking. Eur Rev Med Pharmacol Sci 24:4529-4536. https://doi.org/10.26355/eurrev_202004_21036

Kakar SS, Parte S, Carter K et al (2017) Withaferin A (WFA) inhibits tumor growth and metastasis by targeting ovarian cancer stem cells. Oncotarget 8:43

Kalhor H, Sadeghi S, Abolhasani H, Kalhor R, Rahimi H (2020) Repurposing of the approved small molecule drugs in order to inhibit SARS-CoV-2 S protein and human ACE2 interaction through virtual screening approaches. J Biomol Struct Dyn 1-16. https://doi. org/10.1080/07391102.2020.1824816

Kalikar MV, Thawani VR, Varadpande UK et al (2008) Immunomodulatory effect of Tinospora cordifolia extract in human immuno-deficiency virus positive patients. Indian J Pharmacol 40: 107-110. https://doi.org/10.4103/0253-7613.42302

Karwasra R, Kalra P, Nag TC, Gupta YK, Singh S, Panwar A (2016) Safety assessment and attenuation of cisplatin induced nephrotoxicity by tuberous roots of Boerhaavia diffusa. Regul Toxicol Pharmacol 81:341-352. https://doi.org/10.1016/j.yrtph.2016.09. 020

Katoch D, Sharma JS, Banerjee S, Biswas R, Das B, Goswami D, Harwansh RK, Katiyar CK, Mukherjee PK (2017) Government policies and initiatives for development of Ayurveda. J Ethnopharmacol 197:25-31. https://doi.org/10.1016/j.jep.2016.08. 018

Kaushik S, Kaushik S, Sharma V, Yadav J (2018) Antiviral and therapeutic uses of medicinal plants and their derivatives against dengue viruses. Pharmacogn Rev 12:177

Kaushik S, Jangra G, Kundu V, Yadav JP, Kaushik S (2020a) Anti-viral activity of Zingiber officinale (Ginger) ingredients against the Chikungunya virus. Virusdisease 31:1-7. https://doi.org/10.1007/ s13337-020-00584-0

Kaushik S, Kaushik S, Kumar R, Dar L, Yadav JP (2020b) In-vitro and in silico activity of Cyamopsis tetragonoloba (Gaur) L. supercritical extract against the dengue-2 virus. VirusDisease 31:470-478. https://doi.org/10.1007/s13337-020-00624-9

Kaushik S, Kaushik S, Sharma Y, Kumar R, Yadav JP (2020c) The Indian perspective of COVID-19 outbreak. Virusdisease 31:1-8. https://doi.org/10.1007/s13337-020-00587-x

Kaushik S, Dar L, Kaushik S, Yadav JP (2021) Identification and characterization of new potent inhibitors of dengue virus NS5 proteinase from Andrographis paniculata supercritical extracts on in animal cell culture and in silico approaches. J Ethnopharmacol 267:113541. https://doi.org/10.1016/j.jep.2020.113541

Kesarwani K, Gupta R, Mukerjee A (2013) Bioavailability enhancers of herbal origin: an overview. Asian Pac J Trop Biomed 3:253-266. https://doi.org/10.1016/S2221-1691(13)60060-X 
Kesharwani A, Polachira SK, Nair R, Agarwal A, Mishra NN, Gupta SK (2017) Anti-HSV-2 activity of Terminalia chebula Retz extract and its constituents, chebulagic and chebulinic acids. BMC Complement Altern Med 17:110. https://doi.org/10.1186/s12906-017-1620-8

Khan MTH, Ather A, Thompson KD, Gambari R (2005) Extracts and molecules from medicinal plants against herpes simplex viruses. Antiviral Res 67:107-119. https://doi.org/10.1016/j.antiviral.2005. 05.002

Khanal P, Chikhale R, Dey YN, Pasha I, Chand S, Gurav N, Ayyanar M, Patil BM, Gurav S (2021) Withanolides from Withania somnifera as an immunity booster and their therapeutic options against COVID19. J Biomol Struct Dyn:1-14. https://doi.org/10.1080/07391102. 2020.1869588

Khanna K, Kohli SK, Kaur R, Bhardwaj A, Bhardwaj V, Ohri P, Sharma A, Ahmad A, Bhardwaj R, Ahmad P (2021) Herbal immuneboosters: substantial warriors of pandemic Covid-19 battle. Phytomedicine 85:153361. https://doi.org/10.1016/j.phymed.2020. 153361

Kim H-Y, Zuo G, Lee SK, Lim SS (2020a) Acute and subchronic toxicity study of nonpolar extract of licorice roots in mice. Food Sci Nutr 8: 2242-2250. https://doi.org/10.1002/fsn3.1465

Kim S-H, Hong J-H, Yang W-K, Geum JH, Kim HR, Choi SY, Kang YM, An HJ, Lee YC (2020b) Herbal combinational medication of Glycyrrhiza glabra, Agastache rugosa containing glycyrrhizic acid, tilianin inhibits neutrophilic lung inflammation by affecting CXCL2, interleukin-17/STAT3 signal pathways in a murine model of COPD. Nutrients 12. https://doi.org/10.3390/nu12040926

Kotecha R (2021) The journey with COVID-19: Initiatives by Ministry of AYUSH. J Ayurveda Integr Med 12:1-3. https://doi.org/10.1016/j. jaim.2021.03.009

Kothandan R, Rajan CASG, Arjun J, Raj RRM, Syed S (2021) Virtual screening of phytochemical compounds as potential inhibitors against SARS-CoV-2 infection. Beni-Suef Univ J Basic Appl Sci 10:9. https://doi.org/10.1186/s43088-021-00095-x

Kulshreshta VK, Srivastava RK, Singh N, Kohli RP (1969) A study of central stimulant effect of Piper longum. Indian J Pharmacol 1:8-10

Kumar MCS, Udupa AL, Sammodavardhana K, Rathnakar UP, Shvetha U, Kodancha GP (2010) Acute toxicity and diuretic studies of the roots of Asparagus racemosus Willd in rats. West Indian Med J 59: 3-6

Kumar S, Kamboj J, Suman SS (2011) Overview for various aspects of the health benefits of Piper longum Linn. Fruit. J Acupunct Meridian Stud 4:134-140. https://doi.org/10.1016/S2005-2901(11)60020-4

Kumar D, Arya V, Kaur R, Bhat ZA, Gupta VK, Kumar V (2012) A review of immunomodulators in the Indian traditional health care system. J Microbiol Immunol Infect 45:165-184. https://doi.org/10. 1016/j.jmii.2011.09.030

KUMAR A, Rai AK, Chiluveri AC et al (2021) Ayurvedic paradigm for COVID-19 prophylaxis and management strategies: perspective and evidence-based review. Indian J Tradit Knowl 19:S-25

Lancet T (2021) India's COVID-19 emergency. Lancet 397:1683. https:// doi.org/10.1016/S0140-6736(21)01052-7

Langade D, Kanchi S, Salve J et al (2019) Efficacy and safety of Ashwagandha (Withania somnifera) root extract in insomnia and anxiety: a double-blind, randomized, placebo-controlled study. Cureus 11:e5797. https://doi.org/10.7759/cureus.5797

Latha S, Chamundeeswari D, Seethalakshmi S, Senthamarai R (2020) Attenuation of adjuvant-induced arthrits by Stereospermum colais and Stereospermum suaveolens via modulation of inflammatory mediators. J Ethnopharmacol 249:112394. https://doi.org/10.1016/ j.jep.2019.112394

Lawson-Evi P, Eklu-Gadegbeku K, Agbonon A et al (2008) Toxicological assessment on extracts of Phyllanthus amarus Schum and Thonn. Sci Res Essays 3:410-415

Lee NYS, Khoo WKS, Adnan MA, Mahalingam TP, Fernandez AR, Jeevaratnam K (2016) The pharmacological potential of
Phyllanthus niruri. J Pharm Pharmacol 68:953-969. https://doi. org/10.1111/jphp.12565

Li F (2015) Receptor recognition mechanisms of coronaviruses: a decade of structural studies. J Virol 89:1954 LP-1951964. https://doi.org/ 10.1128/JVI.02615-14

Li F (2016) Structure, function, and evolution of coronavirus spike proteins. Annu Rev Virol 3:237-261. https://doi.org/10.1146/annurevvirology-110615-042301

Li W, Moore MJ, Vasilieva N, Sui J, Wong SK, Berne MA, Somasundaran M, Sullivan JL, Luzuriaga K, Greenough TC, Choe H, Farzan M (2003) Angiotensin-converting enzyme 2 is a functional receptor for the SARS coronavirus. Nature 426:450-454. https:// doi.org/10.1038/nature02145

Li X-L, Zhou A-G, Zhang L, Chen W-J (2011) Antioxidant status and immune activity of glycyrrhizin in allergic rhinitis mice. Int J Mol Sci 12:905-916. https://doi.org/10.3390/ijms12020905

Li C, Eom T, Jeong Y (2015) Glycyrrhiza glabra L. extract inhibits LPSinduced inflammation in RAW macrophages. J Nutr Sci Vitaminol (Tokyo) 61:375-381. https://doi.org/10.3177/jnsv.61.375

Li H, Sureda A, Devkota HP, Pittalà V, Barreca D, Silva AS, Tewari D, $\mathrm{Xu}$ S, Nabavi SM (2019) Curcumin, the golden spice in treating cardiovascular diseases. Biotechnol Adv. 38:107343. https://doi. org/10.1016/j.biotechadv.2019.01.010

Li G, Fan Y, Lai Y, Han T, Li Z, Zhou P, Pan P, Wang W, Hu D, Liu X, Zhang Q, Wu J (2020) Coronavirus infections and immune responses. J Med Virol 92:424-432. https://doi.org/10.1002/jmv. 25685

Lin L-T, Chen T-Y, Chung C-Y, Noyce RS, Grindley TB, McCormick C, Lin TC, Wang GH, Lin CC, Richardson CD (2011) Hydrolyzable tannins (chebulagic acid and punicalagin) target viral glycoproteinglycosaminoglycan interactions to inhibit herpes simplex virus 1 entry and cell-to-cell spread. J Virol 85:4386-4398. https://doi.org/ 10.1128/JVI.01492-10

Lin L-T, Chen T-Y, Lin S-C, Chung CY, Lin TC, Wang GH, Anderson R, Lin CC, Richardson CD (2013) Broad-spectrum antiviral activity of chebulagic acid and punicalagin against viruses that use glycosaminoglycans for entry. BMC Microbiol 13:187. https://doi.org/10. 1186/1471-2180-13-187

Lin L-T, Hsu W-C, Lin C-C (2014) Antiviral natural products and herbal medicines. J Tradit Complement Med 4:24-35. https://doi.org/10. 4103/2225-4110.124335

Liu Y-T, Chen H-W, Lii C-K, Jhuang JH, Huang CS, Li ML, Yao HT (2020a) A diterpenoid, 14-deoxy-11, 12-didehydroandrographolide, in Andrographis paniculata reduces steatohepatitis and liver injury in mice fed a high-fat and high-cholesterol diet. Nutrients 12:523. https://doi.org/10.3390/nu12020523

Liu Z, Xiao X, Wei X, Li J, Yang J, Tan H, Zhu J, Zhang Q, Wu J, Liu L (2020b) Composition and divergence of coronavirus spike proteins and host ACE2 receptors predict potential intermediate hosts of SARS-CoV-2. J Med Virol 92:595-601. https://doi.org/10.1002/ jmv. 25726

Londhe DJ, Shobhit K, Chiluveri Ashwin C et al (2020) Ayurveda research studies on COVID-19 registered in Clinical Trials Registry of India: a critical appraisal. J Res Ayurvedic Sci 4:128-134

Low G, Rogers LJ, Brumley SP, Ehrlich D (1985) Visual deficits and retinotoxicity caused by the naturally occurring anthelmintics, Embelia ribes and Hagenia abyssinica. Toxicol Appl Pharmacol 81:220-230. https://doi.org/10.1016/0041-008x(85)90158-9

Luan R-S, Wang X, Sun X et al (2020) Epidemiology, treatment, and epidemic prevention and control of the coronavirus disease 2019: a review. Sichuan da xue xue bao Yi xue ban $=J$ Sichuan Univ Med Sci Ed 51:131-138. https://doi.org/10.12182/20200360505

Ludvigsson JF (2020) Systematic review of COVID-19 in children shows milder cases and a better prognosis than adults. Acta Paediatr 109: 1088-1095. https://doi.org/10.1111/apa.15270 
Luo G, McHenry ML, Letterio JJ (2020) Estimating the prevalence and risk of COVID-19 among international travelers and evacuees of Wuhan through modeling and case reports. PLoS One 15: e0234955-e0234955. https://doi.org/10.1371/journal.pone. 0234955

Maheshwari RK, Singh AK, Gaddipati J, Srimal RC (2006) Multiple biological activities of curcumin: a short review. Life Sci 78:20812087. https://doi.org/10.1016/j.lfs.2005.12.007

Maity N, Nema NK, Sarkar BK, Mukherjee PK (2012) Standardized Clitoria ternatea leaf extract as hyaluronidase, elastase and matrixmetalloproteinase-1 inhibitor. Indian J Pharmacol 44:584-587. https://doi.org/10.4103/0253-7613.100381

Maji AK, Samanta SK, Mahapatra S, Banerji P, Banerjee D (2014) Invivo immunomodulatory activity of standardized Stereospermum suaveolens (Roxb.) DC. root extract. Orient Pharm Exp Med 14: 47-54. https://doi.org/10.1007/s13596-013-0132-4

Maloir Q, Ghysen K, von Frenckell C, Louis R, Guiot J (2018) Acute respiratory distress revealing antisynthetase syndrome. Rev Med Liege 73:370-375

Mandal A, Jha AK, Hazra B (2021) Plant products as inhibitors of coronavirus 3CL protease. Front Pharmacol 12:583387. https://doi.org/ 10.3389/fphar.2021.583387

Manni ML, Robinson KM, Alcorn JF (2014) A tale of two cytokines: IL17 and IL-22 in asthma and infection. Expert Rev Respir Med 8:2542. https://doi.org/10.1586/17476348.2014.854167

Manoj P, Soniya E V, Banerjee NS, Ravichandran P (2004) Recent studies on well-known spice, Piper longum Linn.

Manosroi A, Jantrawut P, Ogihara E, Yamamoto A, Fukatsu M, Yasukawa K, Tokuda H, Suzuki N, Manosroi J, Akihisa T (2013) Biological activities of phenolic compounds and triterpenoids from the galls of Terminalia chebula. Chem Biodivers 10:1448-1463. https://doi.org/10.1002/cbdv.201300149

Manu KA, Kuttan G (2007) Effect of Punarnavine, an alkaloid from Boerhaavia diffusa, on cell-mediated immune responses and TIMP-1 in B16F-10 metastatic melanoma-bearing mice. Immunopharmacol Immunotoxicol 29:569-586. https://doi.org/10. 1080/08923970701692676

Mehrotra R, Rawat S, Kulshreshtha DK, Goyal P, Patnaik GK, Dhawan BN (1991) In vitro effect of Phyllanthus amarus on hepatitis B virus. Indian J Med Res 93:71-73

Menon CK (1919) Embelia ribes-a medicine for influenza. Indian For 45: 210

Michaelis M, Geiler J, Naczk P, Sithisarn P, Leutz A, Doerr HW, Cinatl J (2011) Glycyrrhizin exerts antioxidative effects in H5N1 influenza A virus-infected cells and inhibits virus replication and proinflammatory gene expression. PLoS One 6:e19705. https://doi. org/10.1371/journal.pone.0019705

Millet JK, Whittaker GR (2015) Host cell proteases: critical determinants of coronavirus tropism and pathogenesis. Virus Res 202:120-134. https://doi.org/10.1016/j.virusres.2014.11.021

Miryan M, Bagherniya M, Sahebkar A, Soleimani D, Rouhani MH, Iraj B, Askari G (2020) Effects of curcumin-piperine co-supplementation on clinical signs, duration, severity, and inflammatory factors in patients with COVID-19: a structured summary of a study protocol for a randomised controlled trial. Trials 21:1027. https://doi.org/10. 1186/s13063-020-04924-9

Mishra S, Aeri V, Gaur PK, Jachak SM (2014) Phytochemical, therapeutic, and ethnopharmacological overview for a traditionally important herb: Boerhavia diffusa Linn. Biomed Res Int 2014:808302808319. https://doi.org/10.1155/2014/808302

Mitra Mazumder P, Pattnayak S, Parvani H, Sasmal D, Rathinavelusamy P (2012) Evaluation of immunomodulatory activity of Glycyrhiza glabra L roots in combination with zing. Asian Pac J Trop Biomed 2:S15-S20. https://doi.org/10.1016/S2221-1691(12)60122-1

Mohamadian M, Chiti H, Shoghli A, Biglari S, Parsamanesh N, Esmaeilzadeh A (2021) COVID-19: Virology, biology and novel laboratory diagnosis. J Gene Med 23:e3303. https://doi.org/10. 1002/jgm.3303

More P, Pai K (2012) In vitro NADH-oxidase, NADPH-oxidase and myeloperoxidase activity of macrophages after Tinospora cordifolia (guduchi) treatment. Immunopharmacol Immunotoxicol 34:368372. https://doi.org/10.3109/08923973.2011.606324

Mpharm TB, Kumar CT (2010) Analgesic and antipyretic activities of ethanol extract of Stereospermum suaveolens. J Diet Suppl 7:104116. https://doi.org/10.3109/19390211003781677

Muhseen ZT, Hameed AR, Al-Hasani HMH et al (2020) Promising terpenes as SARS-CoV-2 spike receptor-binding domain (RBD) attachment inhibitors to the human ACE2 receptor: integrated computational approach. J Mol Liq 320:114493. https://doi.org/10.1016/ j.molliq.2020.114493

Muhseen ZT, Hameed AR, Al-Hasani HMH et al (2021) Computational determination of potential multiprotein targeting natural compounds for rational drug design against SARS-COV-2. Molecules 26. https://doi.org/10.3390/molecules26030674

Mukherjee PK, Harwansh RK, Bahadur S, Banerjee S, Kar A, Chanda J, Biswas S, Ahmmed SM, Katiyar CK (2017) Development of Ayurveda - tradition to trend. J Ethnopharmacol 197:10-24. https://doi.org/10.1016/j.jep.2016.09.024

Mukhtar M, Arshad M, Ahmad M, Pomerantz RJ, Wigdahl B, Parveen Z (2008) Antiviral potentials of medicinal plants. Virus Res 131:111120. https://doi.org/10.1016/j.virusres.2007.09.008

Murck H (2020) Symptomatic protective action of glycyrrhizin (licorice) in COVID-19 infection? Front. Immunol. 11:1239

Muthulakshmi M, Subramani PA, Michael RD (2016) Immunostimulatory effect of the aqueous leaf extract of Phyllanthus niruri on the specific and nonspecific immune responses of Oreochromis mossambicus Peters. Iran J Vet Res 17:200-202

Narayana Moorthy A, Narasaraju T, Rai P, Perumalsamy R, Tan KB, Wang S, Engelward B, Chow VTK (2013) In vivo and in vitro studies on the roles of neutrophil extracellular traps during secondary pneumococcal pneumonia after primary pulmonary influenza infection. Front Immunol 4:56. https://doi.org/10.3389/fimmu. 2013.00056

Narkhede RR, Pise AV, Cheke RS, Shinde SD (2020) Recognition of natural products as potential inhibitors of COVID-19 main protease (Mpro): in-silico evidences. Nat Products Bioprospect 10:297-306. https://doi.org/10.1007/s13659-020-00253-1

Nazari S, Rameshrad M, Hosseinzadeh H (2017) Toxicological effects of Glycyrrhiza glabra (licorice): a review. Phyther Res 31:1635-1650. https://doi.org/10.1002/ptr.5893

Newman DJ, Cragg GM (2020) Natural products as sources of new drugs over the nearly four decades from 01/1981 to 09/2019. J Nat Prod 83:770-803. https://doi.org/10.1021/acs.jnatprod.9b01285

Nicolis E, Lampronti I, Dechecchi MC, Borgatti M, Tamanini A, Bianchi N, Bezzerri V, Mancini I, Grazia Giri M, Rizzotti P, Gambari R, Cabrini G (2008) Pyrogallol, an active compound from the medicinal plant Emblica officinalis, regulates expression of proinflammatory genes in bronchial epithelial cells. Int Immunopharmacol 8:1672-1680. https://doi.org/10.1016/j.intimp. 2008.08.001

Noman A, Aqeel M, Khalid N, Hashem M, Alamari S, Zafar S, Qasim M, Irshad MK, Qari SH (2021) Spike glycoproteins: their significance for corona viruses and receptor binding activities for pathogenesis and viral survival. Microb Pathog 150:104719. https://doi.org/10. 1016/j.micpath.2020.104719

Orlent H, Hansen BE, Willems M, Brouwer JT, Huber R, Kullak-Ublick GA, Gerken G, Zeuzem S, Nevens F, Tielemans WCM, Zondervan PE, Lagging M, Westin J, Schalm SW (2006) Biochemical and histological effects of 26 weeks of glycyrrhizin treatment in chronic hepatitis C: a randomized phase II trial. J Hepatol 45:539-546. https://doi.org/10.1016/j.jhep.2006.05.015 
Ou J-L, Mizushina Y, Wang S-Y, Chuang DY, Nadar M, Hsu WL (2013) Structure-activity relationship analysis of curcumin analogues on anti-influenza virus activity. FEBS J 280:5829-5840. https://doi. org/10.1111/febs. 12503

Pal R, Yadav U (2020) COVID-19 pandemic in India: present scenario and a steep climb ahead. J Prim Care Community Health 11: 2150132720939402. https://doi.org/10.1177/2150132720939402

Pal M, Berhanu G, Desalegn C, Kandi V (2020) Severe acute respiratory syndrome coronavirus-2 (SARS-CoV-2): an update. Cureus 12: e7423-e7423. https://doi.org/10.7759/cureus. 7423

Panahi Y, Hosseini MS, Khalili N, Naimi E, Simental-Mendía LE, Majeed M, Sahebkar A (2016) Effects of curcumin on serum cytokine concentrations in subjects with metabolic syndrome: a post-hoc analysis of a randomized controlled trial. Biomed Pharmacother 82: 578-582. https://doi.org/10.1016/j.biopha.2016.05.037

Pandey R, Maurya R, Singh G, Sathiamoorthy B, Naik S (2005) Immunosuppressive properties of flavonoids isolated from Boerhaavia diffusa Linn. Int Immunopharmacol 5:541-553. https://doi.org/10.1016/j.intimp.2004.11.001

Pandey P, Rane JS, Chatterjee A, Kumar A, Khan R, Prakash A, Ray S (2020) Targeting SARS-CoV-2 spike protein of COVID-19 with naturally occurring phytochemicals: an in silico study for drug development. J Biomol Struct Dyn:1-11. https://doi.org/10.1080/ 07391102.2020 .1796811

Pandit M, Latha N (2020) In silico studies reveal potential antiviral activity of phytochemicals from medicinal plants for the treatment of COVID-19 infection

Pant M, Ambwani T, Umapathi V (2012) Antiviral activity of Ashwagandha extract on infectious bursal disease virus replication. Indian J Sci Technol 5:2750-2751

Parekar RR, Bolegave SS, Marathe PA, Rege NN (2015) Experimental evaluation of analgesic, anti-inflammatory and anti-platelet potential of Dashamoola. J Ayurveda Integr Med 6:11-18. https://doi.org/10. 4103/0975-9476.146565

Patel JR, Tripathi P, Sharma V, Chauhan NS, Dixit VK (2011) Phyllanthus amarus: ethnomedicinal uses, phytochemistry and pharmacology: a review. J Ethnopharmacol 138:286-313. https://doi. org/10.1016/j.jep.2011.09.040

Patel CN, Goswami D, Jaiswal DG, Parmar RM, Solanki HA, Pandya HA (2021) Pinpointing the potential hits for hindering interaction of SARS-CoV-2 S-protein with ACE2 from the pool of antiviral phytochemicals utilizing molecular docking and molecular dynamics (MD) simulations. J Mol Graph Model 105:107874. https://doi. org/10.1016/j.jmgm.2021.107874

Pathak M, Vyas H, Vyas M (2010) A clinical trial of Pippali (Piper longum Linn.) with special reference to Abheshaja. AYU (An Int Q J Res Ayurveda) 31:442-446. https://doi.org/10.4103/0974-8520. 82038

Patwardhan B, Gautam M (2005) Botanical immunodrugs: scope and opportunities. Drug Discov Today 10:495-502. https://doi.org/10. 1016/S1359-6446(04)03357-4

Petrovska BB (2012) Historical review of medicinal plants' usage. Pharmacogn Rev 6:1-5. https://doi.org/10.4103/0973-7847.95849

Pise MV, Rudra JA, Upadhyay A (2015) Immunomodulatory potential of shatavarins produced from Asparagus racemosus tissue cultures. J Nat Sci Biol Med 6:415-420. https://doi.org/10.4103/0976-9668. 160025

Pohl S, Zobel J, Moffat A (2010) Extended Boolean retrieval for systematic biomedical reviews. In: Proceedings of the Thirty-Third Australasian Conferenc on Computer Science - Volume 102. Australian Computer Society, Inc., Darlinghurst, Australia, Australia, pp 117-126

Pompei R, Pani A, Flore O, Marcialis MA, Loddo B (1980) Antiviral activity of glycyrrhizic acid. Experientia 36:304. https://doi.org/10. 1007/BF01952290
Ponnusankar S, Pandit S, Venkatesh M, Bandyopadhyay A, Mukherjee PK (2011) Cytochrome P450 inhibition assay for standardized extract of Terminalia chebula Retz. Phytother Res 25:151-154. https:// doi.org/10.1002/ptr.2993

Praditya D, Kirchhoff L, Brüning J, Rachmawati H, Steinmann J, Steinmann E (2019) Anti-infective properties of the golden spice curcumin. Front Microbiol 10:912. https://doi.org/10.3389/fmicb. 2019.00912

Puthiyedath R, Kataria S, Payyappallimana U, Mangalath P, Nampoothiri V, Sharma P, Singh MK, Kumar K, Trehan N (2020) Ayurvedic clinical profile of COVID-19 - a preliminary report. J Ayurveda Integr Med. https://doi.org/10.1016/j.jaim.2020.05.011

Rajagopal K, Varakumar P, Baliwada A, Byran G (2020) Activity of phytochemical constituents of Curcuma longa (turmeric) and Andrographis paniculata against coronavirus (COVID-19): an in silico approach. Futur J Pharm Sci 6:104. https://doi.org/10.1186/ s43094-020-00126-X

Ranjan D, Chen C, Johnston TD, Jeon H, Nagabhushan M (2004) Curcumin inhibits mitogen stimulated lymphocyte proliferation, NFkappaB activation, and IL-2 signaling. J Surg Res 121:171177. https://doi.org/10.1016/j.jss.2004.04.004

Rasool M, Varalakshmi P (2006) Immunomodulatory role of Withania somnifera root powder on experimental induced inflammation: an in vivo and in vitro study. Vascul Pharmacol 44:406-410. https:// doi.org/10.1016/j.vph.2006.01.015

Raut AA, Rege NN, Tadvi FM et al (2012) Exploratory study to evaluate tolerability, safety, and activity of Ashwagandha (Withania somnifera) in healthy volunteers. J Ayurveda Integr Med 3:111114. https://doi.org/10.4103/0975-9476.100168

Ravikumar YS, Ray U, Nandhitha M, Perween A, Raja Naika H, Khanna $N$, Das S (2011) Inhibition of hepatitis $C$ virus replication by herbal extract: Phyllanthus amarus as potent natural source. Virus Res 158: 89-97. https://doi.org/10.1016/j.virusres.2011.03.014

Reddy AC, Lokesh BR (1992) Studies on spice principles as antioxidants in the inhibition of lipid peroxidation of rat liver microsomes. Mol Cell Biochem 111:117-124. https://doi.org/10.1007/BF00229582

Richart SM, Li Y-L, Mizushina Y, Chang YY, Chung TY, Chen GH, Tzen JTC, Shia KS, Hsu WL (2018) Synergic effect of curcumin and its structural analogue (Monoacetylcurcumin) on anti-influenza virus infection. J food drug Anal 26:1015-1023. https://doi.org/10. 1016/j.jfda.2017.12.006

Rijckborst V, Sonneveld MJ, Janssen HLA (2011) Review article: chronic hepatitis B - anti-viral or immunomodulatory therapy? Aliment Pharmacol Ther 33:501-513. https://doi.org/10.1111/j.1365-2036. 2010.04555.x

Rohaim MA, El Naggar RF, Clayton E, Munir M (2021) Structural and functional insights into non-structural proteins of coronaviruses. Microb Pathog 150:104641. https://doi.org/10.1016/j.micpath. 2020.104641

Rubab I, Ali S (2016) Dried fruit extract of Terminalia chebula modulates the immune response in mice. Food Agric Immunol 27:1-22. https://doi.org/10.1080/09540105.2015.1055554

Rutwick Surya U, Praveen N (2021) A molecular docking study of SARS-CoV-2 main protease against phytochemicals of Boerhavia diffusa Linn. for novel COVID-19 drug discovery. VirusDisease 32: 46-54. https://doi.org/10.1007/s13337-021-00683-6

Sabde S, Bodiwala HS, Karmase A, Deshpande PJ, Kaur A, Ahmed N, Chauthe SK, Brahmbhatt KG, Phadke RU, Mitra D, Bhutani KK, Singh IP (2011) Anti-HIV activity of Indian medicinal plants. J. Nat. Med. 65:662-669

Sachan S, Dhama K, Latheef SK, Samad HA, Mariappan AK, Munuswamy P, Singh R, Singh KP, Malik YS, Singh RK (2019) Immunomodulatory Potential of Tinospora cordifolia and $\mathrm{CpG}$ ODN (TLR21 Agonist) against the Very Virulent, Infectious Bursal Disease Virus in SPF Chicks. Vaccines 7. https://doi.org/ 10.3390/vaccines 7030106 
Saggam A, Limgaokar K, Borse S et al (2021) Withania somnifera (L.) Dunal: opportunity for clinical repurposing in COVID-19 management. Front. Pharmacol 12:835

Sai Ram M, Neetu D, Yogesh B, Anju B, Dipti P, Pauline T, Sharma SK, Sarada SKS, Ilavazhagan G, Kumar D, Selvamurthy W (2002) Cyto-protective and immunomodulating properties of Amla (Emblica officinalis) on lymphocytes: an in-vitro study. J Ethnopharmacol 81:5-10. https://doi.org/10.1016/s0378-8741(01) 00421-4

Saleem S, Muhammad G, Hussain MA et al (2020) Withania somnifera L.: insights into the phytochemical profile, therapeutic potential, clinical trials, and future prospective. Iran J Basic Med Sci 23: 1501-1526. https://doi.org/10.22038/IJBMS.2020.44254.10378

Sannegowda KM, Venkatesha SH, Moudgil KD (2015) Tinospora cordifolia inhibits autoimmune arthritis by regulating key immune mediators of inflammation and bone damage. Int J Immunopathol Pharmacol 28:521-531. https://doi.org/10.1177/ 0394632015608248

Sarin B, Verma N, Martín JP, Mohanty A (2014) An overview of important ethnomedicinal herbs of Phyllanthus species: present status and future prospects. Sci World J 2014:1-12

Sato H, Goto W, Yamamura J et al (1996) Therapeutic basis of glycyrrhizin on chronic hepatitis B. Antiviral Res 30:171-177. https://doi.org/10.1016/0166-3542(96)00942-4

Schoeman D, Fielding BC (2019) Coronavirus envelope protein: current knowledge. Virol J 16:69. https://doi.org/10.1186/s12985-0191182-0

Shah SL, Wahid F, Khan N, Farooq U, Shah AJ, Tareen S, Ahmad F, Khan T (2018) Inhibitory effects of Glycyrrhiza glabra and its major constituent glycyrrhizin on inflammation-associated corneal neovascularization. Evidence-Based Complement Altern Med 2018: 8438101-8438108. https://doi.org/10.1155/2018/8438101

Sharma U, Bala M, Kumar N, Singh B, Munshi RK, Bhalerao S (2012) Immunomodulatory active compounds from Tinospora cordifolia. J Ethnopharmacol 141:918-926. https://doi.org/10.1016/j.jep.2012. 03.027

Sharma V, Katiyar A, Agrawal RC (2018) Glycyrrhiza glabra: chemistry and pharmacological activity BT - sweeteners: pharmacology, biotechnology, and applications. In: Mérillon J-M, Ramawat KG (eds) . Springer International Publishing, Cham, pp 87-100

Sharma V, Kaushik S, Pandit P, Dhull D, Yadav JP, Kaushik S (2019) Green synthesis of silver nanoparticles from medicinal plants and evaluation of their antiviral potential against chikungunya virus. Appl Microbiol Biotechnol 103:881-891. https://doi.org/10.1007/ s00253-018-9488-1

Sharma Y, Kawatra A, Sharma V, Dhull D, Kaushik S, Yadav JP, Kaushik S (2021) In-vitro and in-silico evaluation of the antichikungunya potential of Psidium guajava leaf extract and their synthesized silver nanoparticles. VirusDisease. 32:260-265. https://doi.org/10.1007/s13337-021-00685-4

Shirole RL, Shirole NL, Saraf MN (2015) Embelia ribes ameliorates lipopolysaccharide-induced acute respiratory distress syndrome. J Ethnopharmacol 168:356-363. https://doi.org/10.1016/j.jep.2015. 03.009

Shree P, Mishra P, Selvaraj C, Singh SK, Chaube R, Garg N, Tripathi YB (2020) Targeting COVID-19 (SARS-CoV-2) main protease through active phytochemicals of ayurvedic medicinal plants - Withania somnifera (Ashwagandha), Tinospora cordifolia (Giloy) and Ocimum sanctum (Tulsi) - a molecular docking study. J Biomol Struct Dyn:1-14. https://doi.org/10.1080/07391102.2020.1810778

Shrivastava N, Srivastava A, Banerjee A, Nivsarkar M (2006) Anti-ulcer activity of Adhatoda vasica Nees. J Herb Pharmacother 6:43-49. https://doi.org/10.1080/J157v06n02 04

Siddiqui NA, Singh S, Siddiquei MM, Khan TH (2012) Immunomodulatory effect of Withania somnifera, Asparagus racemosus and Picrorhiza kurroa roots. Int J Pharmacol 8:108-114
Singh N, Kumar S, Singh P, Raj HG, Prasad AK, Parmar VS, Ghosh B (2008) Piper longum Linn. extract inhibits TNF-alpha-induced expression of cell adhesion molecules by inhibiting NF-kappaB activation and microsomal lipid peroxidation. Phytomedicine 15:284 291. https://doi.org/10.1016/j.phymed.2007.06.007

Singh KP, Upadhyay B, Pra R, Kumar A (2010) Screening of Adhatoda vasica Nees as a putative HIV-protease inhibitor. J Phytol 2

Singh MK, Yadav SS, Gupta V, Khattri S (2013) Immunomodulatory role of Emblica officinalis in arsenic induced oxidative damage and apoptosis in thymocytes of mice. BMC Complement Altern Med 13:193. https://doi.org/10.1186/1472-6882-13-193

Singhal T (2020) A review of coronavirus disease-2019 (COVID-19). Indian J Pediatr 87:281-286. https://doi.org/10.1007/s12098-02003263-6

Sinha SK, Prasad SK, Islam MA, Gurav SS, Patil RB, AlFaris NA, Aldayel TS, AlKehayez NM, Wabaidur SM, Shakya A (2020) Identification of bioactive compounds from Glycyrrhiza glabra as possible inhibitor of SARS-CoV-2 spike glycoprotein and nonstructural protein-15: a pharmacoinformatics study. J Biomol Struct Dyn 39:1-15. https://doi.org/10.1080/07391102.2020. 1779132

Somarathna KIWK, Chandola HM, Ravishankar B, Pandya KN, Attanayake AMP (2010) A short-term intervention trial on HIV positive patients using a Sri Lankan classical rasayana drug Ranahamsa Rasayanaya. Ayu 31:197-204. https://doi.org/10.4103/ 0974-8520.72393

Srivastav AK, Gupta SK, Kumar U (2020) Computational studies towards identification of lead herbal compounds of medicinal importance for development of nutraceutical against COVID-19

Straughn AR, Kakar SS (2020) Withaferin A: a potential therapeutic agent against COVID-19 infection. J Ovarian Res 13:79. https:// doi.org/10.1186/s13048-020-00684-x

Suja RS, Nair AMC, Sujith S et al (2009) Evaluation of immunomodulatory potential of Emblica officinalis fruit pulp extract in mice. Indian J Anim Res 43:103-106

Sumathi S, Swathi K, Suganya K, Sudha B, Poornima A, Hamsa D, Kumar S (2021) A broad perspective on COVID-19: a global pandemic and a focus on preventive medicine. Tradit Med Res 6:12

Sunila ES, Kuttan G (2004) Immunomodulatory and antitumor activity of Piper longum Linn. and piperine. J Ethnopharmacol 90:339-346. https://doi.org/10.1016/j.jep.2003.10.016

Suresh K, Vasudevan DM (1994) Augmentation of murine natural killer cell and antibody dependent cellular cytotoxicity activities by Phyllanthus emblica, a new immunomodulator. J Ethnopharmacol 44:55-60. https://doi.org/10.1016/0378-8741(94)90099-x

Tang X, Wu C, Li X, Song Y, Yao X, Wu X, Duan Y, Zhang H, Wang Y, Qian Z, Cui J, Lu J (2020) On the origin and continuing evolution of SARS-CoV-2. Natl Sci Rev 7:1012-1023. https://doi.org/10.1093/ nsr $/$ nwaa036

Tewari D, Mocan A, Parvanov ED, Sah AN, Nabavi SM, Huminiecki L, Ma ZF, Lee YY, Horbańczuk JO, Atanasov AG (2017) Ethnopharmacological approaches for therapy of jaundice: Part II. Highly used plant species from Acanthaceae, Euphorbiaceae, Asteraceae, Combretaceae, and Fabaceae families. Front Pharmacol 8. 8. https://doi.org/10.3389/fphar.2017.00519

Tewari D, Stankiewicz AM, Mocan A, Sah AN, Tzvetkov NT, Huminiecki L, Horbańczuk JO, Atanasov AG (2018) Ethnopharmacological approaches for dementia therapy and significance of natural products and herbal drugs. Front Aging Neurosci 10. https://doi.org/10.3389/fnagi.2018.00003

Tewari D, Rawat P, Singh PK (2019) Adverse drug reactions of anticancer drugs derived from natural sources. Food Chem Toxicol 123: 522-535. https://doi.org/10.1016/j.fct.2018.11.041

Tewari D, Sah AN, Bawari S, Bussmann RW (2020) Ethnobotanical investigations on plants used in folk medicine by native people of Kumaun Himalayan Region of India. Ethnobot Res Appl 20:1-35 
Thakkar SS, Shelat F, Thakor P (2021) Magical bullets from an indigenous Indian medicinal plant Tinospora cordifolia: an in silico approach for the antidote of SARS-CoV-2. Egypt J Pet 30:53-66. https://doi.org/10.1016/j.ejpe.2021.02.005

Thakur M, Bhargava S, Dixit VK (2007) Immunomodulatory activity of Chlorophytum borivilianum Sant. F. Evid Based Complement Alternat Med 4:419-423. https://doi.org/10.1093/ecam/nel094

Thangaraju P, Sudha Ty S, Pasala PK et al (2021) The role of Justicia Adhatoda as prophylaxis for COVID-19 - analysis based on docking study. Infect Disord Drug Targets. https://doi.org/10.2174/ 1871526521666210119120643

Thanigaivel A, Vasantha-Srinivasan P, Senthil-Nathan S, Edwin ES, Ponsankar A, Chellappandian M, Selin-Rani S, Lija-Escaline J, Kalaivani K (2017) Impact of Terminalia chebula Retz. against Aedes aegypti L. and non-target aquatic predatory insects. Ecotoxicol Environ Saf 137:210-217. https://doi.org/10.1016/j. ecoenv.2016.11.004

Thatte UM, Dahanukar SA (1997) Rasayana concept: clues from immunomodulatory therapy in immunomodulation edited by $\mathrm{SN}$ upadhyay

Thatte UM, Kulkarni MR, Dahanukar SA (1992) Immunotherapeutic modification of Escherichia coli peritonitis and bacteremia by Tinospora cordifolia. J Postgrad Med 38:13-15

Thimmulappa RK, Mudnakudu-Nagaraju KK, Shivamallu C, Subramaniam KJT, Radhakrishnan A, Bhojraj S, Kuppusamy G (2021) Antiviral and immunomodulatory activity of curcumin: a case for prophylactic therapy for COVID-19. Heliyon 7:e66350. https://doi.org/10.1016/j.heliyon.2021.e06350

Tønnesen HH, Másson M, Loftsson T (2002) Studies of curcumin and curcuminoids. XXVII. Cyclodextrin complexation: solubility, chemical and photochemical stability. Int J Pharm 244:127-135. https://doi.org/10.1016/s0378-5173(02)00323-x

Upadhyay S, Tripathi PK, Singh M, Raghavendhar S, Bhardwaj M, Patel AK (2020) Evaluation of medicinal herbs as a potential therapeutic option against SARS-CoV-2 targeting its main protease. Phytother Res 34:3411-3419. https://doi.org/10.1002/ptr.6802

Urra JM, Cabrera CM, Porras L, Ródenas I (2020) Selective CD8 cell reduction by SARS-CoV-2 is associated with a worse prognosis and systemic inflammation in COVID-19 patients. Clin Immunol 217: 108486. https://doi.org/10.1016/j.clim.2020.108486

Vajragupta O, Boonchoong P, Morris GM, Olson AJ (2005) Active site binding modes of curcumin in HIV-1 protease and integrase. Bioorg Med Chem Lett 15:3364-3368. https://doi.org/10.1016/j.bmcl. 2005.05.032

van der Meijden AP (2001) Non-specific immunotherapy with bacille Calmette-Guérin (BCG). Clin Exp Immunol 123:179-180. https:// doi.org/10.1046/j.1365-2249.2001.01449.x

van Oosterhout C, Hall N, Ly H, Tyler KM (2021) COVID-19 evolution during the pandemic - implications of new SARS-CoV-2 variants on disease control and public health policies. Virulence 12:507-508. https://doi.org/10.1080/21505594.2021.1877066

Vellingiri B, Jayaramayya K, Iyer M, Narayanasamy A, Govindasamy V, Giridharan B, Ganesan S, Venugopal A, Venkatesan D, Ganesan H, Rajagopalan K, Rahman PKSM, Cho SG, Kumar NS, Subramaniam MD (2020) COVID-19: a promising cure for the global panic. Sci Total Environ 725:138277. https://doi.org/10.1016/j.scitotenv.2020. 138277

Vimalanathan S, Ignacimuthu S, Hudson JB (2009) Medicinal plants of Tamil Nadu (Southern India) are a rich source of antiviral activities. Pharm Biol 47:422-429. https://doi.org/10.1080/ 13880200902800196
Vinothapooshan G, Sundar K (2011) Immunomodulatory activity of various extracts of Adhatoda vasica Linn. in experimental rats. African J Pharm Pharmacol 5:306-310

Wahab Sab BA, Jacob J, Manjunath GG et al (2015) Cycloolivil, a lignan from the roots of Stereospermum suaveolens. Pharmacognosy Res 7:45-48. https://doi.org/10.4103/0974-8490.147198

Wang X-R, Hao H-G, Chu L (2017) Glycyrrhizin inhibits LPS-induced inflammatory mediator production in endometrial epithelial cells. Microb Pathog 109:110-113. https://doi.org/10.1016/j.micpath. 2017.05.032

Wang D, Hu B, Hu C, Zhu F, Liu X, Zhang J, Wang B, Xiang H, Cheng Z, Xiong Y, Zhao Y, Li Y, Wang X, Peng Z (2020) Clinical characteristics of 138 hospitalized patients with 2019 novel coronavirusinfected pneumonia in Wuhan, China. JAMA 323:1061-1069. https://doi.org/10.1001/jama.2020.1585

Wei Z-Q, Zhang Y-H, Ke C-Z, Chen HX, Ren P, He YL, Hu P, Ma DQ, Luo J, Meng ZJ (2017) Curcumin inhibits hepatitis B virus infection by down-regulating cccDNA-bound histone acetylation. World J Gastroenterol 23:6252-6260. https://doi.org/10.3748/wjg.v23.i34. 6252

Wen C-C, Kuo Y-H, Jan J-T, Liang PH, Wang SY, Liu HG, Lee CK, Chang ST, Kuo CJ, Lee SS, Hou CC, Hsiao PW, Chien SC, Shyur LF, Yang NS (2007) Specific plant terpenoids and lignoids possess potent antiviral activities against severe acute respiratory syndrome coronavirus. J Med Chem 50:4087-4095. https://doi.org/10.1021/ jm070295s

Williams TC, Burgers WA (2021) SARS-CoV-2 evolution and vaccines: cause for concern? Lancet Respir Med 9:333-335. https://doi.org/ 10.1016/S2213-2600(21)00075-8

Wu Y, Li J, Kim Y, Wu J, Wang Q, Hao Y (2011) In vivo and in vitro antiviral effects of berberine on influenza virus. Chin J Integr Med 17:444-452. https://doi.org/10.1007/s11655-011-0640-3

Xu Z, Shi L, Wang Y, Zhang J, Huang L, Zhang C, Liu S, Zhao P, Liu H, Zhu L, Tai Y, Bai C, Gao T, Song J, Xia P, Dong J, Zhao J, Wang FS (2020) Pathological findings of COVID-19 associated with acute respiratory distress syndrome. Lancet Respir Med 8:420-422. https://doi.org/10.1016/S2213-2600(20)30076-X

Yadav V, Krishnan A, Vohora D (2020) A systematic review on Piper longum L.: bridging traditional knowledge and pharmacological evidence for future translational research. J Ethnopharmacol 247: 112255. https://doi.org/10.1016/j.jep.2019.112255

Yamamoto H, Morino K, Mengistu L, Ishibashi T, Kiriyama K, Ikami T, Maegawa H (2016) Amla enhances mitochondrial spare respiratory capacity by increasing mitochondrial biogenesis and antioxidant systems in a murine skeletal muscle cell line. Oxid Med Cell Longev 2016:1735841-1735811. https://doi.org/10.1155/2016/ 1735841

Yarnell E (2017) Herbs for viral respiratory infections. Altern Complement Ther 24:35-43. https://doi.org/10.1089/act.2017. 29150.eya

Yukawa TA, Kurokawa M, Sato H, Yoshida Y, Kageyama S, Hasegawa T, Namba T, Imakita M, Hozumi T, Shiraki K (1996) Prophylactic treatment of cytomegalovirus infection with traditional herbs. Antiviral Res 32:63-70. https://doi.org/10.1016/0166-3542(95) 00978-7

Ziauddin M, Phansalkar N, Patki P, Diwanay S, Patwardhan B (1996) Studies on the immunomodulatory effects of Ashwagandha. J Ethnopharmacol 50:69-76. https://doi.org/10.1016/0378-8741(95) 01318-0

Publisher's note Springer Nature remains neutral with regard to jurisdictional claims in published maps and institutional affiliations. 